Review

\title{
New Highlights of Resveratrol: A Review of Properties against Ocular Diseases
}

\author{
Dominique Delmas ${ }^{1,2,3, *}$, Clarisse Cornebise ${ }^{1,2}$, Flavie Courtaut ${ }^{1,2}$, Jianbo Xiao ${ }^{4,5,6}$ (D) and Virginie Aires ${ }^{1,2}$ \\ 1 Université de Bourgogne Franche-Comté, F-21000 Dijon, France; clarisse.cornebise@gmail.com (C.C.); \\ flavie.courtaut@gmail.com (F.C.); virginie.aires02@u-bourgogne.fr (V.A.) \\ 2 INSERM Research Center U1231, Cancer and Adaptive Immune Response Team, \\ Bioactive Molecules and Health Research Group, F-21000 Dijon, France \\ 3 Centre Anticancéreux Georges François Leclerc, F-21000 Dijon, France \\ 4 Nutrition and Bromatology Group, Department of Analytical Chemistry and Food Science, \\ Faculty of Food Science and Technology, University of Vigo-Ourense Campus, E-32004 Ourense, Spain; \\ jianboxiao@yahoo.com \\ 5 College of Food Science and Technology, Guangdong Ocean University, Zhanjiang 524088, China \\ 6 International Research Center for Food Nutrition and Safety, Jiangsu University, Zhenjiang 212013, China \\ * Correspondence: dominique.delmas@u-bourgogne.fr; Tel.: +33-380-39-32-26
}

Citation: Delmas, D.; Cornebise, C.; Courtaut, F.; Xiao, J.; Aires, V. New Highlights of Resveratrol: A Review of Properties against Ocular Diseases. Int. J. Mol. Sci. 2021, 22, 1295.

https://doi.org/10.3390/ijms22031295

Academic Editors: Janusz Blasiak and Kai Kaarniranta

Received: 10 December 2020

Accepted: 24 January 2021

Published: 28 January 202

Publisher's Note: MDPI stays neutral with regard to jurisdictional claims in published maps and institutional affiliations.

Copyright: (c) 2021 by the authors. Licensee MDPI, Basel, Switzerland. This article is an open access article distributed under the terms and conditions of the Creative Commons Attribution (CC BY) license (https:// creativecommons.org/licenses/by/ $4.0 /)$.

\begin{abstract}
Eye diseases are currently a major public health concern due to the growing number of cases resulting from both an aging of populations and exogenous factors linked to our lifestyles. Thus, many treatments including surgical pharmacological approaches have emerged, and special attention has been paid to prevention, where diet plays a preponderant role. Recently, potential antioxidants such as resveratrol have received much attention as potential tools against various ocular diseases. In this review, we focus on the mechanisms of resveratrol against ocular diseases, in particular agerelated macular degeneration, glaucoma, cataract, diabetic retinopathy, and vitreoretinopathy. We analyze, in relation to the different steps of each disease, the resveratrol properties at multiple levels, such as cellular and molecular signaling as well as physiological effects. We show and discuss the relationship to reactive oxygen species, the regulation of inflammatory process, and how resveratrol can prevent ocular diseases through a potential epigenetic action by the activation of sirtuin-1. Lastly, various new forms of resveratrol delivery are emerging at the same time as some clinical trials are raising more questions about the future of resveratrol as a potential tool for prevention or in therapeutic strategies against ocular diseases. More preclinical studies are required to provide further insights into RSV's potential adjuvant activity.
\end{abstract}

Keywords: resveratrol; polyphenols; nutraceutical; ocular diseases; eyes; AMD; angiogenesis; diabetic retinopathy; cataract

\section{Introduction}

The number of visually impaired people of all ages is estimated to be 285 million worldwide, of whom 39 million are blind [1]. The leading causes of blindness and low vision are primarily age-related eye diseases such as age-related macular degeneration (AMD), cataract, diabetic retinopathy (DR), and glaucoma. The molecular mechanisms seem to be involved in many common steps, such as early oxidative stress, an inflammatoryassociated process, and often over-angiogenesis. Visual impairment is a major global health issue, partly due to an aging world population, and the search for preventive or therapeutic strategies is therefore an important issue. Thus, of the dietary microcomponents that can participate in these strategies against ocular diseases, polyphenols could be good candidates (Figure 1). Indeed, various studies have shown that polyphenols may protect against numerous diseases (i.e., vascular diseases, cancers, and associated inflammatory disorders) [2-4]. These phytomolecules have cellular targets similar to those of the new drugs developed by pharmaceutical companies. Indeed, more than 1600 patents are currently 
reported concerning flavonoids and 3000 patents concerning polyphenols. Pleiotropic pharmaceutical activities are claimed in fields such as cancer, inflammatory arthritis, eye diseases, and many other domains. One of the best known is the polyphenol resveratrol, which is a trans-3,4',5-trihydroxystilbene (Trans-RSV) (Figure 1) and appears to be of great interest in the prevention of these pathologies. Resveratrol (RSV) presents a myriad of beneficial health effects and acts at multiple levels such as cellular signaling, enzymatic pathways, apoptosis, and gene expression to prevent or fight coronary heart damage, cancer, and degenerative diseases in in vitro and in vivo studies [5-8]. Due to its multiple biological properties, RSV could help fight the main molecular events of ocular pathologies through its antioxidant power, as well as its anti-inflammatory and anti-angiogenic properties. In this review, we focus only on RSV with whom we have been working for more than 20 years on the elucidation of biological properties and also because it is one of the only polyphenols so that there are both very many robust studies on the molecular mechanisms on several ocular pathologies but also some clinical studies. Thus, this present review concentrates on the current knowledge of the mechanism of RSV on some of the main ocular disorders such as AMD, glaucoma, cataract, and DR. We describe cellular and molecular actions of RSV, as well as its potential epigenetic action in ocular disease prevention. Furthermore, a number of clinical trials have been conducted to test the efficacy of RSV in some cases of AMD. Lastly, we discuss the potential use of RSV and its new formulations in association with other therapeutic drugs.

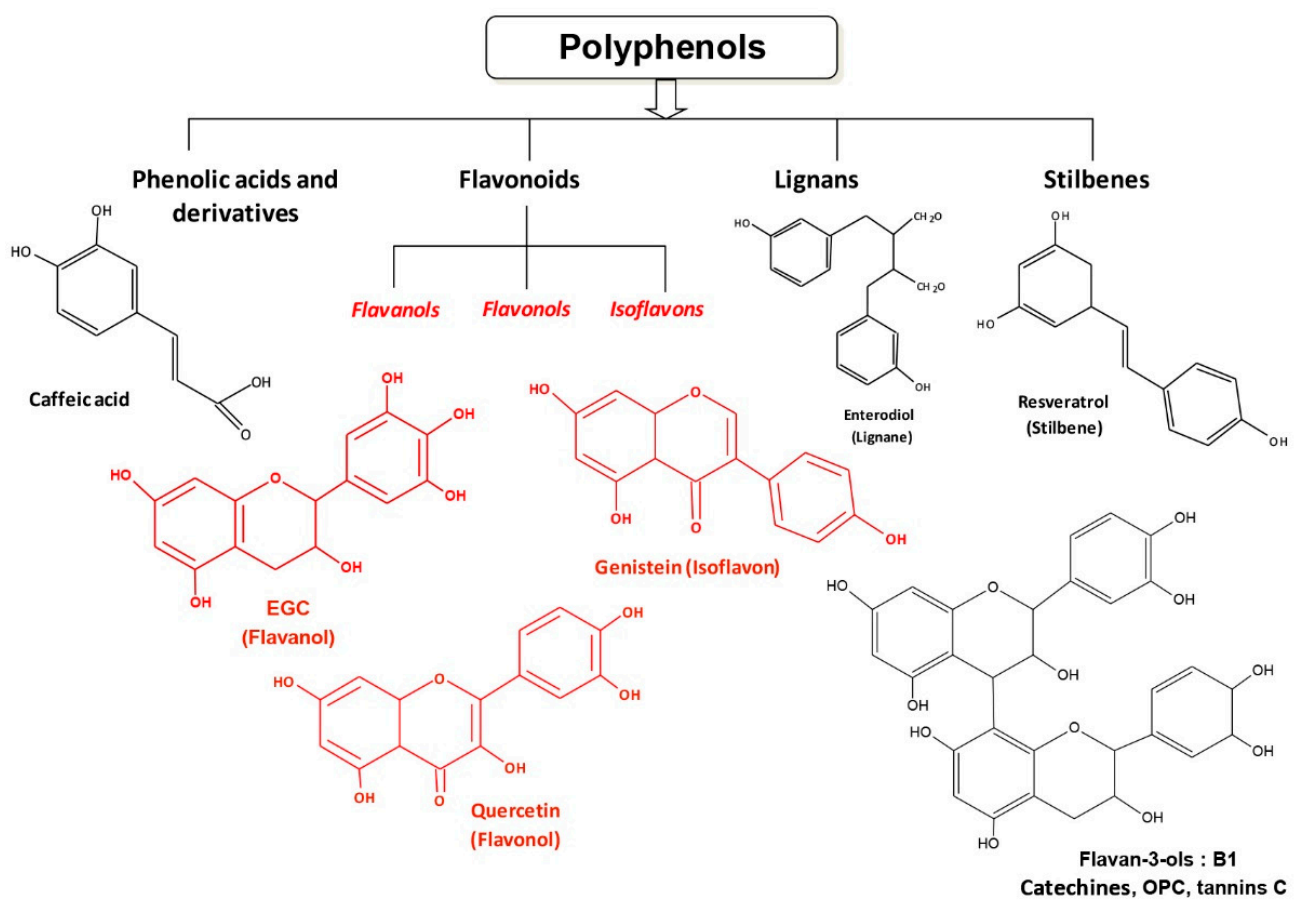

Figure 1. Chemical structures of polyphenols. Polyphenols that are ubiquitous in plants can be divided into four classes: phenolic acids such as caffeic acid, flavonoids including quercetin and genistein, the lignans, and the stilbenes, to which resveratrol belongs.

\section{The Origins of Resveratrol}

RSV is a secondary metabolite produced in a small number of plant species. It was first isolated in 1940 from the root of Veratrum grandiflorum, which is a common flower of the Eurasian grasslands [9]. The root of the word "resveratrol" is a combination of the Latin prefix Res, meaning "which comes from", veratr, from the plant "Veratrum", and the suffix ol, indicating that it contains "alcohol" chemical groups. Veratrum grandiflorum has been reported to synthesize RSV and analogues. It is interesting to note that root powder of Veratrum album has long been used at medium altitude in Northern Europe, Asia, and Japan to treat rheumatism and nervous diseases. However, Veratrum album contains potent toxic alkaloids: the protoveratrines A \& B. The RSV precursor is phenylalanine and the 
key cellular enzyme is stilbene synthase, which initiates the synthesis pathway toward RSV instead of toward flavonoids through chalcone synthase [10]. Therefore, RSV can be classified either as a stilbene or as a polyphenol (Figure 1).

Firstly, a significant amount is found in the leaves when the plant is damaged by chemical treatments [11]; secondly, the roots and rhizomes are relatively rich in RSV and, as such, were used as a crude preparation to treat hypertension in the East (Table 1) [12].

One of the richest sources of RSV is Japanese knotweed (barnbuo japonaise) Polygonum cuspidatum, root extract. These roots play an important role in ancient Chinese and Japanese natural medicine $[13,14]$. Its presence has been reported in many trees including eucalyptus [15,16], the spruce [17], and tropical trees like Bauhinia racemosa [18]. RSV has been identified in a small number of flowering plants; only two species of hellebore, Veratrum grandiflorum and Veratrum formosanum, are able to synthesize this compound. RSV is also present in Pterolobium hexapetallum, a legume [19]. Cotyledons such as peanut Arachis hypogaea synthesize a set of stilbene-phytoalexins including RSV with concentrations significantly increased in response to infection, injury, and ultra-violet (UV) irradiation [20-24].

The importance of RSV in plant biology lies in its ability to inhibit the growth of fungal infection, a property that has allowed it to be included in the class of antibiotic plants: phytoalexins. Due to its function as a phytoalexin and its role as a marker of infection by various pathogens, this interest in RSV mainly concerns vines (Vitaceae). The first report describing the structure and presence of RSV in grapes and its induction by infection with a fungus such as Botrytis cinerea [25-27] showed that this hydroxystilbene can exist in two forms: trans-RSV, the most organic form actively blocking the development of Botrytis cinerea, and cis-RSV obtained by the action of light on the trans-form. Most grape varieties contain varying quantities of this natural fungicide molecule, with grape skin containing about $50-100 \mu \mathrm{g}$ of RSV per gram. It follows that during maceration, which takes place in the process of red wine vinification, RSV is dissolved in the hydro-alcoholic medium and then found in abundance in red wine, i.e., up to $20 \mathrm{mg} / \mathrm{L}$ [28]. Furthermore, RSV can be converted into viniferin by the action of vacuolar peroxidases [27,29]. Methyl-transferase and glucosyl-transferase activities have been identified to explain the biosynthesis of pterostilbene and RSV glucosides (including piceid and RSV-3-O- $\beta$-D-glucoside) [30-32].

Table 1. Trans-resveratrol (Trans-RSV) concentrations in various food sources.

\begin{tabular}{ccc}
\hline Sources & Trans-RSV $(\mu \mathrm{g} / \mathrm{g})$ & References \\
\hline Hop & 0.5 & {$[33]$} \\
Peanuts & 5.1 & {$[34]$} \\
Peanut butter & 0.3 & {$[34]$} \\
Grape skin & 27.5 & {$[35]$} \\
Kojo-Kon & 523 & {$[34]$} \\
Blueberries & 0.03 & {$[36]$} \\
\hline
\end{tabular}

Like many other plant polyphenols, RSV is considered to be a preventive food microcomponent in the same way as the flavonoids and epicatechins of green tea or cocoa [37]. In fact, RSV attracted little interest until 1992, when it was postulated to explain some cardioprotective effects of red wine, with interest then increasing from 1997 when Pezzuto's team published a seminal paper reporting the ability of RSV to inhibit carcinogenesis at multiple stages [38]. Since then, the number of papers and citations have increased in an exponential manner due to the pleiotropic effects of RSV on various diseases (Figure 2). The main properties of RSV were found to relate to its antioxidant power, its anti-inflammatory properties, and its ability to modulate various targets in numerous pathologies (Figure 2) such as:

(1) Coronary heart diseases, via scavenging of reactive oxygen species (ROS) [39-41], prevention of the oxidation of low-density lipoproteins (LDL) [42-44], a decrease in foam cell formation and pro-inflammatory molecules [45,46], as well as a reduction in platelet aggregation [47-49]. 
(2) Cancers, through its ability to inhibit carcinogenesis at multiple stages (initiation, promotion, and tumor progression) in in vivo models of skin tumors [38]. Systemic administration of RSV has since been shown to inhibit the initiation and growth of tumors in a wide variety of rodent cancer models through various mechanisms, including cell cycle arrest, induction of apoptosis, and inhibition of angiogenesis (see for review $[7,50])$.

(3) Inflammatory diseases, where RSV is able to modulate both the adaptive and the innate immune response and consequently decrease the production of various proinflammatory cytokines in response to a wide range of exogenous stimuli $[2,6]$.

(4) Age-related degenerative diseases, through its capacity to activate an important actor, sirtuin-1 (Sirt-1), which exhibits down-regulated expression in multiple organs during aging $[51,52]$.

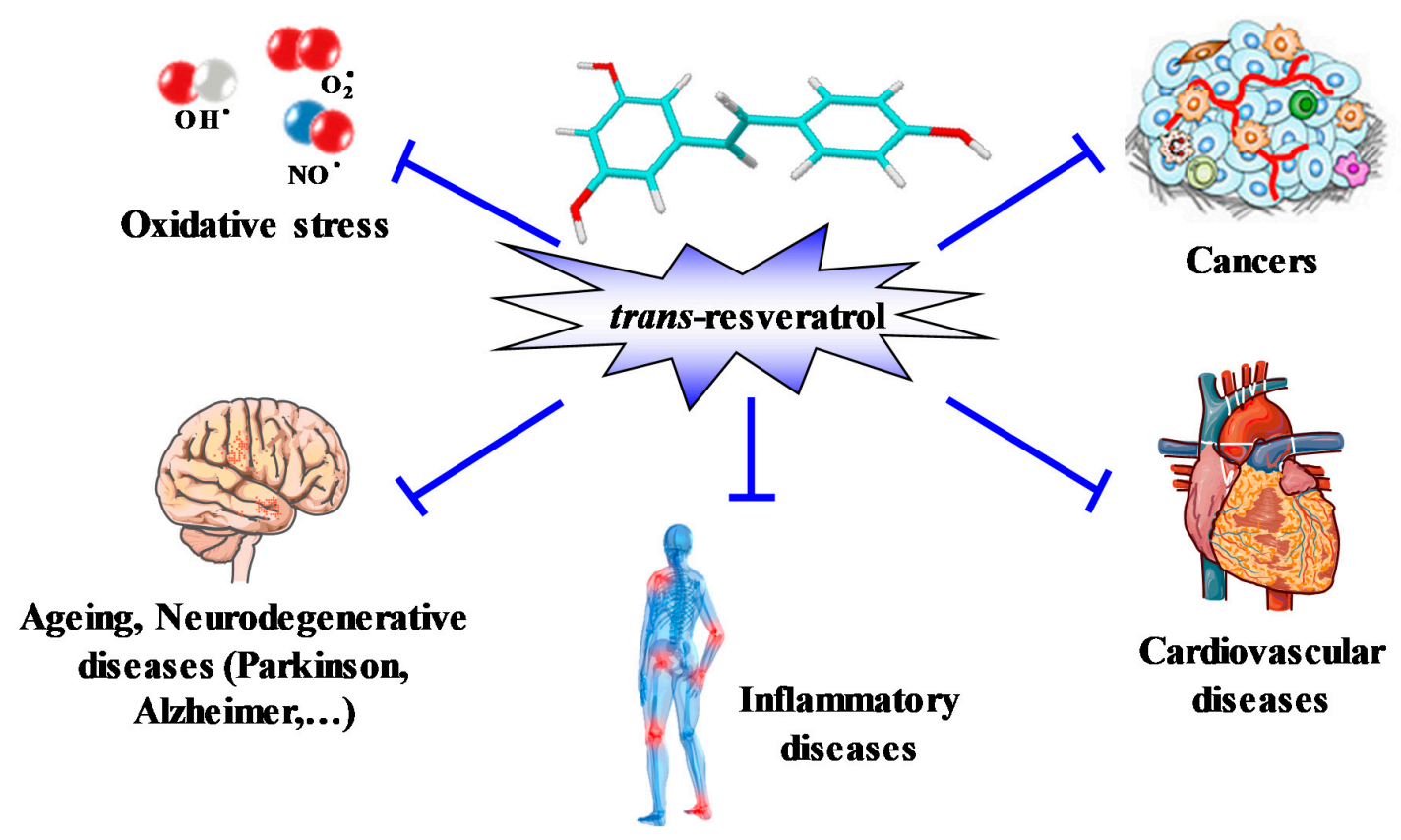

Figure 2. Pleiotropic action of RSV. The 3,4',5-trihydroxystilbene is able to prevent coronary heart diseases, inflammatory pathologies, oxidative stress in aging, neurodegenerative diseases, as well as cancers.

Therefore, these properties of polyphenol could participate in a chemopreventive or chemotherapeutic strategy against ocular diseases such as age-related macular degeneration (AMD), cataract, retinal degeneration, optic neuritis, glaucoma, and retinoblastoma through common mechanisms, as well as through specificities that characterize individual ocular diseases.

\section{Age-Related Macular Degeneration and RSV Action}

\subsection{AMD and the Key Actors}

AMD is one of the main causes of deterioration of vision in elderly people in developed countries [53], resulting in a loss of vision in the center of the visual field due to damage to the retina. It is usually classified as one of two forms: a dry form characterized by the appearance of drusens, which are proteinaceous collections at the level of the retinal pigment epithelium (RPE); and a wet form, in which neovascularization complicates retinal changes. At present, some therapies are used for wet AMD to inhibit the abnormal growth of blood vessels with VEGF inhibitors or laser photocoagulation, but a number of side effects to these therapies are seen, as is resistance. Concerning dry AMD, currently only nutritional supplementation is given; no therapies have shown efficacy. The aim of non-exudative AMD treatment is to delay the loss of visual function. 
Some therapies that modulate risk factors are able to prevent the development or progression of the pathology, but do not completely cure patients affected by AMD. Consequently, new therapies are needed and RSV could act on this disease at different levels. Indeed, keys processes have been identified in AMD such as oxidative damage, impaired activity or function of the RPE, increased apoptosis, and chronic inflammation (Figure 3). Moreover, neovascularization seems to play a very important role in AMD complications. RVS could act on these different steps mainly through its antioxidant power, anti-inflammatory action, or through its anti-angiogenic effects.

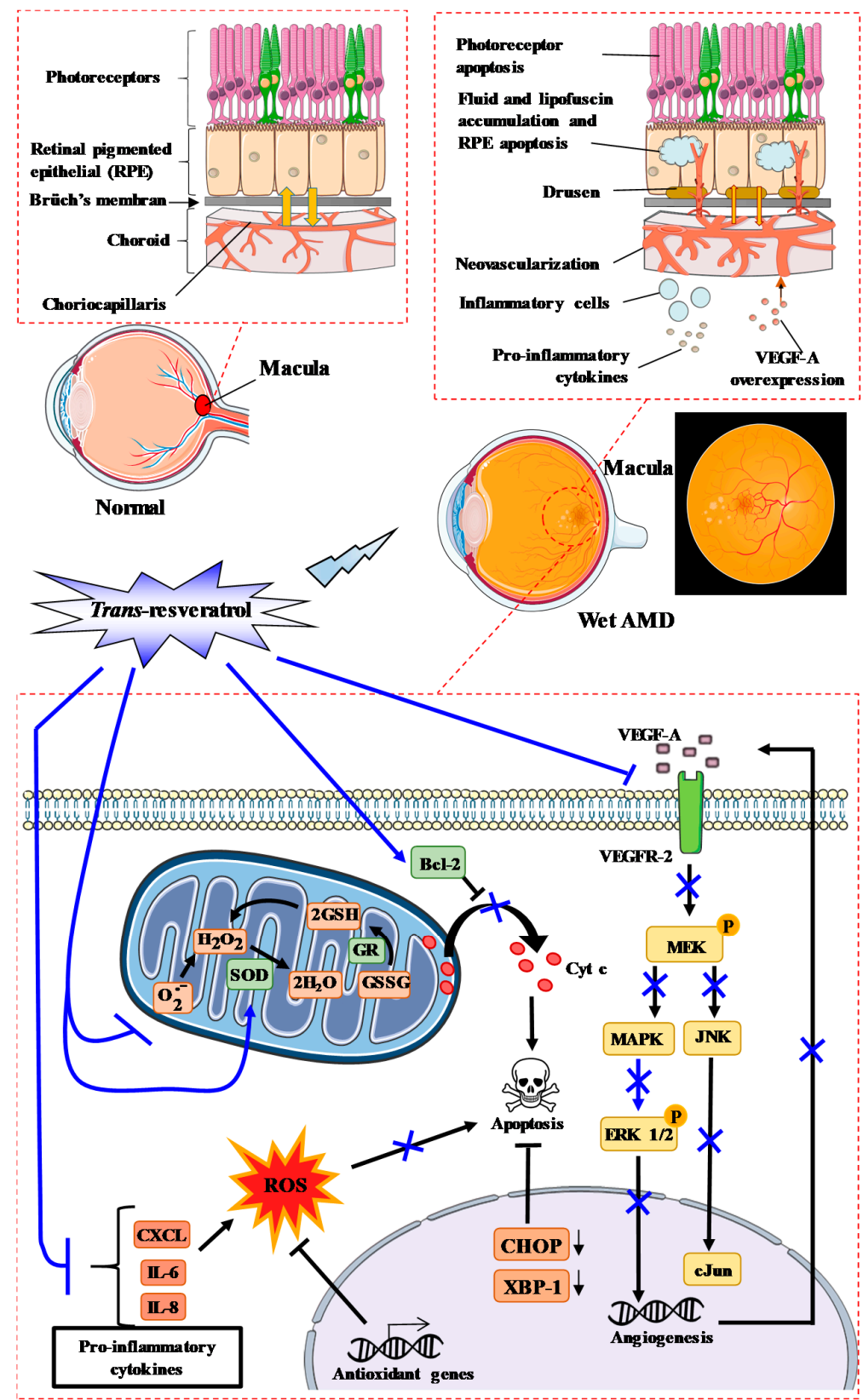

Figure 3. RSV could prevent oxidative stress involved in the development and progression of ocular diseases such as age-related macular degeneration (AMD). Various environmental factors produce free radicals, leading to oxidative stress in ocular tissues and consequently provoking the initiation of diseases such as AMD. On the one hand, RSV is able to scavenge free radicals $\left(\mathrm{O}_{2}{ }^{-}\right)$and activate superoxide dismutase (SOD) or glutathione reductase (GR), while on the other, it inhibits inflammation through the reduction of various pro-inflammatory cytokines and blocks the signaling pathway induced by vascular endothelial growth factor-A (VEGF-A) to promote neoangiogenesis. 


\section{2. $R S V$ and $A M D$ Initiation}

AMD is a multifactorial disease with both environmental and genetic risk factors [54]: air pollution, smoking, UV radiation, metabolic diseases (e.g., diabetes, hypertension, obesity), dietary fat consumption [55-58], and genetic polymorphisms such as cfh, arms $2 /$ hrta1 genes [59]. Alone or in combination, these factors could contribute to initiating AMD through the production of free radicals such as superoxide anion $\left(\mathrm{O}_{2}{ }^{-}\right)$, nitric oxide (NO), and hydroxyl radical $\left(\mathrm{OH}^{\circ}\right)$, which create oxidative stress and inflammation in ocular tissues. It is now well-established that oxidative stress and inflammation play a critical role in the initiation and development of AMD [60].

Due to its antioxidant power and ability to scavenge free radicals, RSV could protect ocular tissues against oxidative stress (Figure 3). RPE cells, which form the cell layer responsible for maintaining retinal health by providing structural and nutritional support, are the primary target for AMD-associated oxidative stress [61]. Due to its antioxidant power, RSV could be effective at reducing the risk of AMD in the same manner as antioxidants commonly found in fruits and vegetables (vitamins $\mathrm{C}, \mathrm{E}$, and carotenoids) for which studies have demonstrated that their intake may delay or prevent the development of retinal diseases [62]. Indeed, the treatment of RPE cells with RSV prevents ROS production, both in the basal state (around 20\% compared to untreated controls) and when cells are treated with an inducer of oxidative stress such as hydrogen peroxide $\left(\mathrm{H}_{2} \mathrm{O}_{2}\right)$. Secondly, RSV protects or delays cell death induced by $\mathrm{H}_{2} \mathrm{O}_{2}$ in RPE cells. Indeed, King et al. have shown that the pretreatment of cells with RSV followed by treatment with $\mathrm{H}_{2} \mathrm{O}_{2}$ prevents the inhibition of cell proliferation [63]. Moreover, polyphenol protected against the oxidative damage of RPE cells by modulating SOD/MDA (malondialdehyde) activity and activating Bcl-2 expression [64]. These protective actions of RSV could involve the inhibition of mitogen-activated protein kinase (MAPK) pathways induced by oxidative stress. At the basal level, RSV was able to decrease the phosphorylation of extracellular signal-regulated kinase $1 / 2$ (ERK 1/2), phospho-ERK1/2, in a dose-dependent manner, as well as the tyrosine/threonine mitogen-activated kinase kinase (MEK), especially with 25 and $50 \mu \mathrm{M}$ RSV compared to cells treated with $\mathrm{H}_{2} \mathrm{O}_{2}$ alone [63]. This ability to reduce MAPK activation could contribute to a reduction in the effect of $\mathrm{H}_{2} \mathrm{O}_{2}$ on this pathway.

Other environmental factors, such as acrolein found in cigarette smoke, induce oxidative stress in human retinal cells. A study performed at the ophthalmology department in Taiwan showed that RSV pretreatment can also prevent damage caused by exposure to acrolein for 7 days followed by $\mathrm{H}_{2} \mathrm{O}_{2}$ treatment $[65,66]$. In the same way, other studies have shown that RSV, alone or in combination with polyunsaturated fatty acids (PUFA; Resvega ${ }^{\circledR}$ ), was able to improve RPE cell viability upon cigarette smoke-derived hydroquinone exposure and reduce the release of interleukin (IL)-8 and monocytic chemoattractant protein (MCP)-1 from RPE cells $[67,68]$. Under these conditions, RSV upregulated C/EBP homologous protein (Chop) and spliced X-box binding protein 1 (XBP1), thereby improving mitochondrial bioenergetics, upregulating antioxidant genes, and stimulating the unfolded protein response $[68,69]$.

UV radiation, especially UVA, can also penetrate the lens, reach the retina, and induce oxidative stress in RPE cells. RSV was able to: (i) reduce the UVA-induced decrease in RPE cell viability, (ii) reduce the generation of intracellular $\mathrm{H}_{2} \mathrm{O}_{2}$, and (iii) decrease the activation of UVA-induced extracellular signal-regulated kinase, c-jun- $\mathrm{NH}_{2}$ terminal kinase, and p38 kinase in RPE cells, as well as cyclooxygenase-2 (COX-2) expression [70].

In a similar manner at our laboratory, we have shown that the toxic effects of oxysterols, which come from the diet or from cholesterol catabolism and play important roles in AMD, could be counteracted by RSV [71]. Indeed, when retinal cells (ARPE-19) were treated with 7-beta-hydroxycholesterol $(7 \beta-\mathrm{OH})$ or with 7-ketocholesterol $(7 \mathrm{KC})$, we observed a decrease in viable cells after $24 \mathrm{~h}$ and more strongly after $40 \mathrm{~h}$. RSV, which has no toxic effect on retinal cells, can protect these cells from the toxic effects of oxysterols. 
Other antioxidant mechanisms of RSV may be involved. Indeed, we have shown in various cell lines that RSV could act on ROS production via its action on mitochondrial enzymatic pathways [7].

RSV can interfere with mitochondrial electron transport and promotes a fall in the mitochondrial transmembrane potential $\Delta \psi_{\mathrm{m}}[72,73]$, a decrease in ATP production, and the generation of ROS (Figure 3) [74]. RSV has also been described to: (1) decrease complex III activity by competing with coenzyme Q, whose complex is the site of ROS production, (2) inhibit ATPase activity, and (3) scavenge superoxide anions [75]. Furthermore, $\mathrm{O}_{2}{ }^{-}$radicals are converted to $\mathrm{H}_{2} \mathrm{O}_{2}$ by superoxide dismutase (SOD), and $\mathrm{H}_{2} \mathrm{O}_{2}$ detoxification normally occurs according to two different reactions, i.e., either by the thioredoxine reductase (TR) or by reacting with glutathione reductase (GSH) and glutathione peroxidase (GPx). The latter reaction produces water and oxidized glutathione (GSSG), and GSSG is recycled to GSH by glutathione reductase (GR). Therefore, in addition to scavenger $\mathrm{O}_{2}{ }^{-}, \mathrm{RSV}$ accelerates the detoxification of $\mathrm{O}_{2}{ }^{-}$by inducing an increase in glutathione levels and also by inducing GPx, GR, glutathione-S-transferase (GST), and catalase (CAT) activities [76-80], as well as their mRNAs levels [81]. This modulation of antioxidant enzymes could explain the inhibition of DNA damage in human lymphocytes induced by various toxic drugs (i.e., $\mathrm{H}_{2} \mathrm{O}_{2}$, 1,2-dimethylhydrazine, bleomycin) [82-84].

Metabolic diseases can also play an essential role in the production of oxidative stress. It is now well-defined that diabetes and obesity have numerous effects on ocular diseases [85]. A wide range of evidence implies that dietary hyperglycemia is etiologically related to human aging and diseases, including DR and AMD. In this context, these diseases can be considered as retinal metabolic diseases. A number of clinical trials have been published investigating the effects of RSV on whole-body energy metabolism in relation to the multiple health factors that are affected by obesity and type 2 diabetes [86-90]. Indeed, daily administration of 2.5 or $5 \mathrm{~g}$ RSV for 28 days shows a decrease of fasting and postprandial glucose and insulin. At low concentrations such as $5 \mathrm{mg}$ twice daily for 4 weeks, RSV significantly decreased insulin resistance [91]. Timmers et al. showed that $75 \mathrm{mg}$ of RSV twice daily for 30 days improved the metabolic profile in a healthy obese man: RSV reduced sleeping and resting metabolic rates [88]. In muscle, RSV activated the AMPK-SIRT1-PGC1 $\alpha$ axis, reduced blood glucose and insulin levels, reduced liver fat, improved muscle mitochondrial function, and reduced inflammatory markers in the blood [88]. Consequently, through the pleiotropic action of RSV on metabolic diseases, this polyphenol could contribute to reducing the collateral effects of metabolic diseases on eye disorders, especially AMD.

A final and important mechanism in this step of AMD initiation is the accumulation of lipofuscin or cellular debris in RPE. Lipofuscin, an aging pigment, is considered to be a credible marker for the aging of cells. Lipofuscin tends to accumulate even at an early age, but rapidly progresses with the advancement of the aging process, suggesting the inability of autophagy to handle the waste disposal capacity. The decline of autophagy during aging appears to be the cause for lipofuscin accumulation. Morselli et al. showed that transgenic expression of Sirt-1 induces autophagy in human cells in vitro and in C. elegans in vivo [92]. Caloric restriction and RSV promotes longevity through the Sirt-1-dependent induction of autophagy [93]. Moreover, RSV induced autophagy in ARPE-19 cells, as determined by the increased presence of autophagic vacuoles, increased the LC3II/I ratio, and decreased p62 expression [94]. In this study, RSV acted similarly to proteasomal inhibition downstream of the mammalian target of rapamycin (mTOR), since upstream inhibition of autophagy by 3-methyladenine was not able to inhibit autophagy in ARPE19 cells. This effect on autophagy is also found with a combination between RSV and PUFA (especially omega-3), where $288 \mathrm{ng}$ of Resvega ${ }^{\circledR}$, containing $30 \mathrm{mg}$ of trans-RSV and $665 \mathrm{mg}$ of omega-3 fatty acids, among other nutrients, was able to induce autophagy and contribute to the survival of ARPE-19 cells exposed to detrimental protein waste triggered by proteasome inhibition [95]. 
RSV was also able to prevent the toxic effects of N-retinyl-N-retinylidene ethanolamine (A2E), a major lipofuscin component that accumulates in RPE cells with age. Indeed, polyphenol pretreatment strengthened cell monolayer integrity through the preservation of trans-epithelial electrical resistance, maintained the intracellular redox balance, and prevented A2E-induced mitochondrial network fragmentation [96]. Moreover, RSV and its metabolite, piceatannol, reduced intracellular A2E accumulation in RPE cells [97].

\subsection{RSV and Inflammatory Processes Related to AMD}

We and others have shown that RSV is an efficient anti-inflammatory compound in various models of cardiovascular disease, cancer, and chronic inflammatory diseases [5,50,98]. Inflammation also plays a central role in ocular pathologies, especially in AMD [99-101], and thus the use of RSV to counteract inflammatory processes could be relevant herein.

Based on the important role played by interleukins, a study has shown that RSV was able to reduce the production of interleukin-6 (IL-6) and interleukin-8 (IL-8) induced by glucose in retinal cells [102]. This latter interleukin, IL-8, has been shown to be an important risk factor for AMD [101]. Furthermore, RSV substantially inhibited pro-inflammatory cytokine-induced CXCL11 production, which is an important chemokine involved in inflammatory cell recruitment [103]. Indeed, RPE cells adjacent to drusen deposits in the AMD eye are known to contain CXCL11. This is not the only chemokine modulated by RSV-this polyphenol was also able to inhibit the cytokine-induced expression of chemokines CXCL9, CCL2, and CCL5.

Another mechanism could involve peroxisome proliferator-activator receptors (PPAR). Indeed, RSV protects RPE cells from sodium iodate injury (increasing levels of ROS and IL-8) through the activation of $\operatorname{PPAR} \alpha$ and alteration of PPAR $\delta$ conformation [104].

\subsection{RSV Can Prevent Complications of AMD}

The ultimate step in the AMD process is neovascularization, which constitutes a major complication of AMD. The molecular mechanisms involve vascular endothelial growth factor A (VEGF-A) and an increase in vascular permeability that results in loss of vision [105]. Anti-angiogenic therapies targeting VEGF have proven to be highly effective in treating neovascular AMD, but they cause a number of side effects. In this approach of angiogenesis inhibition, RSV could counteract AMD through its action on VEGF contributing to the abnormal growth of blood vessels. To test this hypothesis, we tested the protective effect of RSV on the VEGF secretion induced by oxysterols in RPE cells [71]. Oxysterols induced VEGF-A secretion after 24 and $40 \mathrm{~h}$ of treatment with $7 \beta$-hydroxycholesterol and 25-hydroxycholesterol. Interestingly, cotreatment with RSV at $1 \mu \mathrm{M}$ decreased VEGF-A secretion induced by these oxysterols both at 24 and $40 \mathrm{~h}$ [71].

Consequently, RSV could reduce neovascularization or protect against various factors that induce VEGF-A production and promote neovascularization such as diabetes, which is known to induce VEGF and which is linked to the progression of vision loss (see below). In this regard, Kim et al. have shown, in retinal tissues, that RSV pretreatment can prevent diabetes-induced rises in VEGF secretion [106]. Notably, they observed an increase in VEGF levels between the outer plexiform layer and the nerve fiber layer on retinal sections of mice 2 months after the induction of diabetes compared to control mice. Indeed, the authors showed that RSV pretreatment of mice by oral gavage at $20 \mathrm{mg} / \mathrm{kg}$ once a day for 4 weeks prevents VEGF secretion as well as VEGF expression. Moreover, RSV was able to reduce both epidermal growth factor-A (EGF-A) and VEGF-C secretion by human RPE cells stimulated with a mixture of inflammatory cytokines (interferon [IFN]- $\gamma$, tumor necrosis factor $[\mathrm{TNF}]-\alpha, \mathrm{IL}-1 \beta)$ and to decrease tumor growth factor (TGF- $\beta$ ) and cobalt chloride [107]. This potential effect on hypoxia has been raised in several other studies where RSV inhibited hypoxic choroidal vascular endothelial cell proliferation through activation of the stress-activated protein kinase (SAPK)/Jun amino-terminal kinase (JNK) pathway [108]. The development of choroidal neovascularization (CNV) is a critical step in the pathogenesis of AMD, and laser photocoagulation has been described to induce 
$\mathrm{CNV}$ in mice. A preclinical study has shown that $\mathrm{CNV}$ volume was significantly lower in the RSV-treated mice 1 week after laser treatment compared with vehicle-treated animals. Very interestingly, RSV inhibited macrophage infiltration into RPE-choroid and suppressed the expression of inflammatory and angiogenic molecules, including VEGF, monocyte chemotactic protein-1 (MCP-1), and intercellular adhesion molecule-1 (ICAM-1) [109]. The underlining molecular mechanism appeared to involve the maintenance of adenosine monophosphate-activated protein kinase (AMPK) levels, this latter exerting its inhibitory effect on the nuclear factor- $\mathrm{KB}(\mathrm{NF} \kappa \mathrm{B})$ in the RPE-choroid complex.

\section{Glaucoma and RSV Action}

\subsection{Glaucoma and the Key Actors}

Glaucoma is a progressive optic neuropathy defined by damage to the optic nerve associated with the degeneration of retinal ganglion cells (RGC), causing visual field damage and subsequent blindness. Ocular hypertonia $(\mathrm{OH})$ is the first known risk factor that contributes in most cases to the pathology and remains to date the only pathogenic event accessible to medical or surgical treatment. Glaucoma is the second leading cause of blindness in the world after cataracts. It has been projected to affect 80 million people worldwide by 2020 [110] and 112 million people by 2040 [111]. The pathological elevation of intra-ocular pressure (IOP) is due to alteration and then degeneration of the trabecular meshwork. Aqueous humor ( $\mathrm{AH})$ is eliminated at a rate of $90 \%$ by the trabecular route through the trabeculum and at a rate of $10 \%$ by the so-called uveoscleral route. The trabeculum is considered a dynamic filter that drains $\mathrm{AH}$ out of the anterior chamber of the eye. It is located in the iridocorneal angle over its entire circumference. Therapy is based on either medical, laser, or surgical intervention. However, recent works tend to show that a nutritional prevention strategy could be interesting. Indeed, certain lifestyle habits could influence glaucoma progression or its prevention. For exemple, frequency of coffee intake may be associated with disease progression [112].

\subsection{RSV and the Oxidative Stress in Glaucoma}

Oxidative stress is known to be an early event in hydrostatic pressure-induced RGC damage involved in glaucoma. Indeed, several studies have revealed that oxygen metabolism, and more particularly, ROS are crucial in the development of glaucoma. As described previously, RSV has antioxidant properties that, through its hydroxyl groups, have the ability to react with ROS in glaucoma [113]. Nevertheless, this is not RSV's only antioxidant ability. In fact, many studies have demonstrated that RSV can reduce ROS in glaucoma models (in vitro and in vivo) through several pathways (Figure 4) [114-116]. This downregulation of ROS could be due to the modulation of the endogenous antioxidant system [117], such as induction of nuclear factor erythroid-2-related factor 2 (Nrf2) translocation into the nucleus, where it binds to antioxidant response elements (ARE). This latter leads to the production of heme oxygenase-1 (HO-1), an anti-oxidant enzyme [117,118]. 


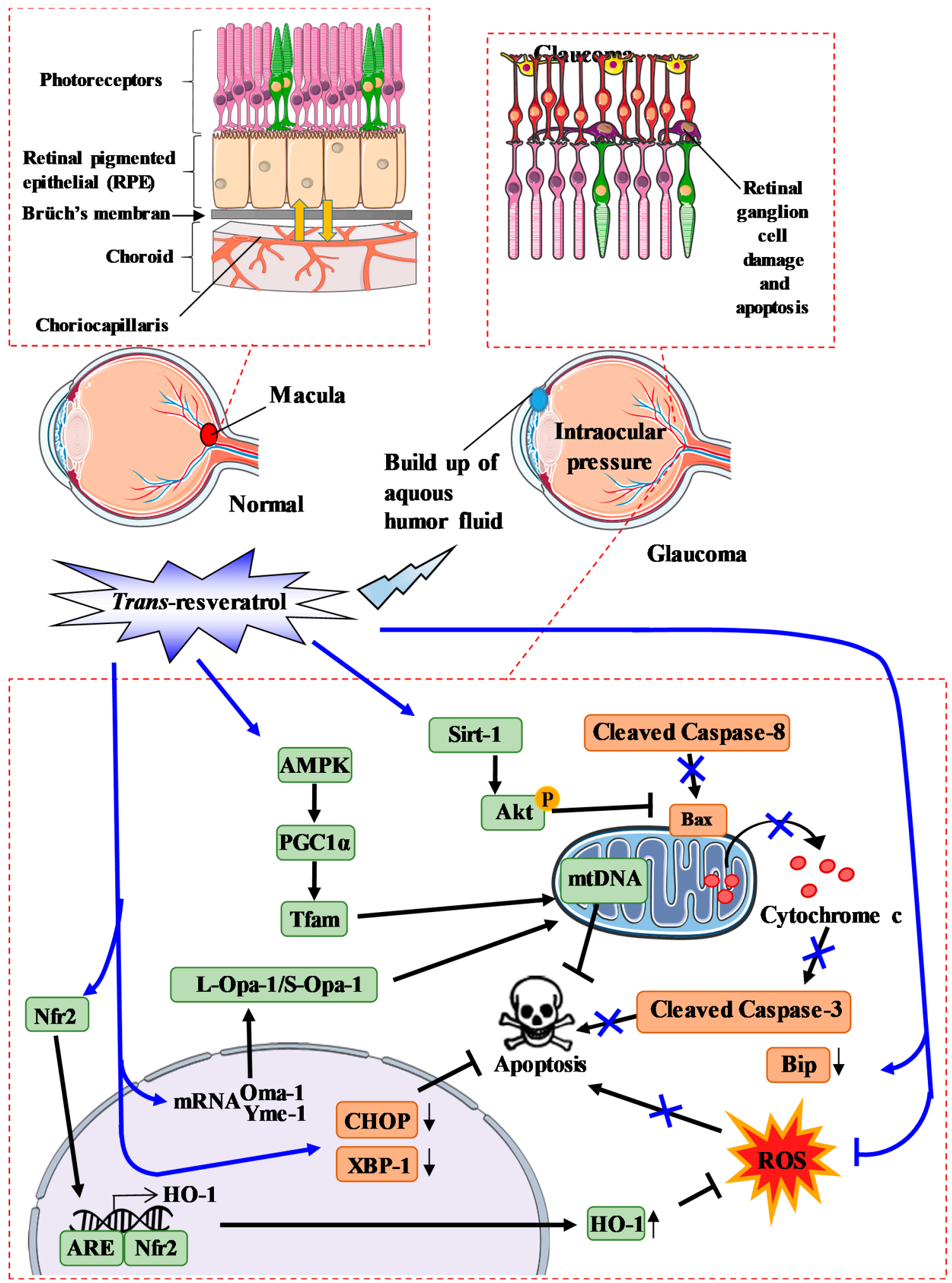

Figure 4. Proposed model of resveratrol action during oxidative stress in glaucoma. Trans-resveratrol (RSV) activates sirtuin-1 (Sirt-1), which leads to the phosphorylation of Akt and inhibits Bax activity. RSV also activates the AMPK pathway, which leads to mitochondrial DNA transcription and replication. RSV is also able to alter Oma-1 and Yeme-1 mRNA expression, leading to the alteration of the L-Opa-1/S-Opa-1 (long-optical autophagy 1/short optical autophagy) ratio. In addition, RSV also lowers ROS levels not only by activating the scavenger pathway, but also by facilitating the translocation of Nrf2 into the nucleus, thereby favoring interaction between Nfr2 and the antioxidant response element (ARE) leading to $\mathrm{HO}$ - production. 
Another important pathway regulating ROS production is the mitochondrial pathway. Indeed, mitochondria are crucial organelles in glaucoma, and oxidative stress can be produced by an imbalance between ROS production and ROS defenses. A significant decrease in the activity of detoxifying enzymes such as SOD and GPx has been shown in the aqueous humor of patients with glaucoma [119]. Thus, targeting mitochondrial homeostasis could be a potential therapy for glaucoma. Some studies have shown that RSV can alter not only the quantity but also the quality of mitochondria in RGC. Indeed, it has been shown that RSV is able to increase the number of mitochondria present in one cell [120] and can affect pathways leading to mitochondrial biogenesis. In this way, RSV is able to downregulate the Oma- 1 gene and upregulate the Yeme- 1 gene, which increase the ratio L-Opa-1/S-Opa-1 (long-optical autophagy 1/short optical autophagy 1) involved in mitochondrial fusion (Figure 4) [121]. Moreover, RSV is able to restore protein levels that are decreased in glaucoma and which are involved in mitochondrial biogenesis, such as AMPK, peroxisome proliferator-activated receptor $\gamma$ coactivator- $1 \alpha$ (PGC-1 $\alpha$ ), and mitochondrial transcription factor A (Tfam), which leads to mitochondrial DNA transcription and replication [115]. Zhang et al. have also shown that RSV modifies not only the number but also the quality of mitochondria by maintaining mitochondrial integrity. Indeed, RSV are able to decrease the membrane potential depolarization induced by pressure.

\subsection{RSV and the Cell Death Process in Glaucoma}

RGCs are the main cell type affected in optic neuropathies, with degeneration of these cells leading to profound phenotypes and eventual loss of vision. It has been reported that the pathways of RGC loss have been explored in depth after acute high IOP injury, such as apoptosis, autophagy, and necrosis. Furthermore, pyroptosis, a novel type of pro-inflammatory cell programmed necrosis, plays a crucial role in retinal neuronal death, especially in the ganglion cell layer, by acute high IOP injury that peaks at $6 \mathrm{~h}$ [122]. Several other in vitro and in vivo studies have shown that RSV treatment or pre-treatment before inducing stress reduces cell apoptosis. For instance, in various glaucoma models, RSV has been demonstrated to reduce the activation of caspase-3, as evidenced by the decrease in cleaved caspase-3 protein expression levels [121,123,124]. In a mouse model of ischemia/reperfusion (I/R) injury, RSV was shown to alter the extrinsic apoptosis pathway by reducing caspase- 8 mRNA levels and proteolytic cleavage in mice retina [123]. Furthermore, other studies have investigated the mitochondrial apoptosis pathway, and showed that RSV can also reduce the expression of Bax and decrease cytochrome $\mathrm{c}$ release. Similarly, another study has been carried out to investigate the effect of RSV on the endoplasmic reticulum (ER) stress apoptosis pathway [125]. This study revealed that RSV reduces the level of cytosolic Bip and also reduces the nuclear quantity of XBP- 1 and CHOP, which consequently reduces apoptotic rates [125]. In a preclinical study, C57BL/6J male mice were injected with RSV for 2 consecutive days before I/R retinal injury, which induces apoptosis in RGCs. In this model, RSV treatment significantly reduced the loss of retinal morphology and downregulated mRNA expression and activation of caspase- 8 and caspase- 3 protein and subsequently reduced apoptosis [123]. These observations were also confirmed in vitro by others [126].

\subsection{RSV and the Inflammatory Process in Glaucoma}

Neuro-inflammation in glaucomatous pathology is a component due to the role of immune and glial cells in the early stages of the pathology. In fact, astrocytes, microglia, and monocytic cells are defined as being critical players in the neuro-inflammatory response in glaucoma. Therefore, a number of studies have investigated the potential inflammatory effect of RSV on trabecular meshwork (TM) endothelial cells. Indeed, it has been shown that the induction of the inflammatory markers IL- $1 \alpha$, IL-6, IL-8, and endothelial leucocyte adhesion molecule-1 (ELAM-1) in TM cells subjected to chronic oxidative stress is dependent on the activation of intracellular ROS (iROS) generated by the mitochondria. RSV 
could be used to reduce the iROS production that results from oxidative stress. A study recently demonstrated that RSV could be used to lower IL- $1 \alpha$ levels. In this study, authors showed that IL- $1 \alpha$ levels were unrelated to those of ELAM-1 [127]. This suggests that other mechanisms could be affected in glaucomatous TM cells. Furthermore, Luna et al. showed that RSV prevents inflammatory markers such as IL- 6 and IL-8 in TM cells under chronic oxidative stress conditions [128]. Another mechanism that could be involved is the activation of adenosine A1 receptors, which may lead to increased matrix metalloproteinase 2 (MMP-2) activity. Razzali et al. have shown that the repeated topical application of RSV for 21 days in steroid-induced ocular hypertensive ( $\mathrm{SIOH}$ ) rats significantly reduces IOP and TM thickness [129]. In these in vivo experiments, RSV also significantly increased ganglion cell layer thickness, the linear cell density in these cells, and inner retinal thickness. Furthermore, it also significantly reduced retinal oxidative stress compared to the SIOH vehicle-treated group. Interestingly, pretreatment with an A1 antagonist abolished the oculohypotensive effect of RSV, suggesting that its oculohypotensive action involves its agonistic activity at the A1 adenosine receptor [130]. In a model of IOP-induced retinal ischemia in rats, RSV was able to reduce detrimental effects due to ischemia through a potential downregulation of MMP-9 and inducible nitric oxide synthase (iNOS), as well as through the upregulation of HO-1 [116].

\section{Cataract and RSV Action}

Cataract is the partial or total clouding of the lens. It is a ubiquitous condition that affects an increasing number of people around the world every year. The risk factors of cataract development are similar to those of AMD and include a wide range of lifestyle parameters (i.e., smoking, alcohol, fatty diet, stress, etc.), although there are also rarer etiologies, as well as traumatic and congenital factors. Furthermore, the main risk factors for age-related cataracts are glaucoma and diabetes, which can lead to secondary cataracts.

The extent of cataract formation significantly increases with age in ad libitum-fed mice. Strikingly, this increase was attenuated by RSV treatment, which was more effective than in the every-other-day-feeding group at 30 months of age [131]. In an experimental model of naphthalene $(1 \mathrm{~g} / \mathrm{kg} /$ day, po)-induced age-related cataract in rats, RSV (20 and $40 \mathrm{mg} / \mathrm{kg} /$ day, i.p.) retarded lenticular opacity, restored antioxidants (CAT, SOD, GPX, GSH), $\mathrm{Ca}^{2+}$ ATPase function, protein contents, and reduced lipid peroxidation in the lenses of RSV-treated rats [132]. RSV was able to significantly inhibit the TGF $\beta 2$-induced expression of the myofibroblast marker, $\alpha$-SMA, in a human lens cell line (FHL124) and human capsular bags following simulated cataract surgery, indicating the ability of RSV to prevent the EMT associated with posterior capsule opacification (PCO). [133]. Interestingly, in cultured lens epithelial cells, RSV inhibited apoptosis and decreased acetyl-p53 levels under oxidative stress induced by $\mathrm{H}_{2} \mathrm{O}_{2}$ [134].

\section{Diabetic Retinopathy and RSV Action}

DR is one of the most common complications of type I and type II diabetes. About $80 \%$ of patients who have lived with diabetes for 15 years have clinical signs of retinopathy and more than $10 \%$ of them are affected by vision loss. This latter is the consequence of slow and progressive alterations in the microvessels of the retina, leading to the opening of the blood-retinal barrier (BRB), the pathological proliferation of blood vessels, and the formation of fibrous tissue in the vitreous cavity, resulting in retinal detachment. During this pathology, neuroglial dysfunction, significant oxidative stress, as well as inflammation and angiogenesis are found. In addition, an increase in the permeability of the retinal vasculature is observed, as well as migration of leukocytes into the retina. Moreover, alterations in biochemical pathways, such as increased flux of advanced glycation end products/receptors (AGE/RAGE), the polyol pathway, protein kinase C (PKC) activation, and the hexosamine pathway induced by hyperglycemia, produce oxidative stress and cause the rupture of the BRB, pericyte loss, and increased vascular permeability [135]. At present, the recommended treatment for severe non-proliferative and proliferative DR 
is photocoagulation and intravitreal injections of anti-VEGF, with or without focal laser treatment for diabetic macular edema.

RSV is able to prevent oxidative stress due to its pleiotropic actions on various key actors. Indeed, RSV was shown to be able to significantly decrease ROS production by increasing retinal SOD activity, which is one of the most important antioxidant defense systems in the retina [136-138]. Conversely, RSV decreased retinal 8-iso-prostaglandin $\mathrm{F}_{2 \alpha}\left(\mathrm{iPF}_{2 \alpha}\right)$, a marker of oxidative damage, and reduced glutathione levels [138-140]. Very interestingly, RSV was able to affect the MAP kinase pathway by inducing phosphorylation of protein kinase B (Akt), for which a reduction is observed in retinal neurodegeneration $[138,141]$, phosphorylation of AMPK, Sirt-1 expression, and PGC- $1 \alpha$ protein expression [137], and decreasing phosphorylation of ERK 1/2 (Figure 5) [138]. Consequently, RSV increased the thickness of both the whole retina and the inner nuclear layer in diabetic rats [138].

RSV significantly attenuated diabetes-induced downregulation of occludin and diabetesinduced upregulation of high-mobility group box-1 (HMGB1), as well as the receptor for advanced glycation end products and BRB breakdown in diabetic retina [142].

Very interestingly, RSV restored the insulin level and paraoxonase 1 (PON1) expression and activity, as well as clearly reducing retinal vascular permeability, retinal AGEs, low-density lipoprotein (LDL), oxidized LDL (Ox-LDL), caspase-3 activity, and retinal damage in STZ-induced diabetic rats $[139,143]$. Moreover, in the same model, RSV decreased various pro-inflammatory cytokines such as IL-1 $\beta$, IL-6, TNF $\alpha$, VEGF, IFN $\gamma$, MCP-1 [143], and NFKB, as well as TNF $\alpha$ and apoptosis [144]. In this pathway involving NFKB, RSV prevented the increase in p65 acetylation, the binding of p65 at the metalloproteinase MMP-9 promoter, and MMP-9 activation, as well as mitochondrial damage and retinal endothelial cell apoptosis [145]. In another model using high-glucose (HG)-stimulated rat retinal endothelial cells (RRECs), RSV reduced caspase-3 activity and Ox-LDL expression [143]. Thus, hyperglycemia and oxidative-osmotic nitrosative stress play a role in the pathophysiology of diabetic cataract (Figure 5). RSV in combination with nicotinamide exhibits strong effects; it was shown that RSV ( 10 or $30 \mathrm{mg} / \mathrm{kg} /$ day) was not able to prevent the onset of diabetic cataract, but significantly delayed its progression compared to the control group [146].

Mechanistically, the delayed progression due to RSV was shown to be linked to a decrease in protein carbonyl levels in diabetic lenses [146], to the inhibition of the aldose reductase enzyme, and to the reduction in the formation of glycation end products in rat lens [147]. Moreover, in a glucose-induced lens opacity model, RSV displayed a protective effect by preventing opacification in cattle lens. These results suggest that RSV partially delays diabetic cataracts through the attenuation of oxidative damage to lens proteins [146]. This prevention of oxidative damage in lens epithelial cells seemed to be mediated by various processes, such as SOD-1, HO-1, CAT, forkhead box O (FoxO) activity, in particular FoxO1A, FoxO3A, and FoxO4, or inhibition of P38 and JNK phosphorylation $[148,149]$.

Very interestingly, RSV at a dose of $40 \mathrm{mg} / \mathrm{kg} /$ day (i.p. injection) in a model of naphthalene $(1 \mathrm{~g} / \mathrm{kg} /$ day, po)-induced age-related cataract (ARC), prevented cataract formation associated with aging through an increase in soluble proteins and $\mathrm{Ca}^{2+}$ homeostasis (i.e., $\mathrm{Ca}^{2+}$ ATPase pump activities in the lens) [132].

By acting on the key actors of the cellular matrix, RSV could prevent posterior capsule opacification (PCO), which is a common complication of cataract surgery. Indeed, RSV was able to inhibit suppressed expression of TGF- $\beta 2$-induced genes associated with fibrotic disease, including in the treatment of STZ-induced diabetic cataract [150]. In general, the cellular pathways induced by DR lead to apoptosis of retinal cells. RSV was able to suppress STZ-induced apoptosis of retinal cells in the inner nuclear layer of retina after administration of $10 \mathrm{mg} / \mathrm{kg} /$ day for 7 months. 


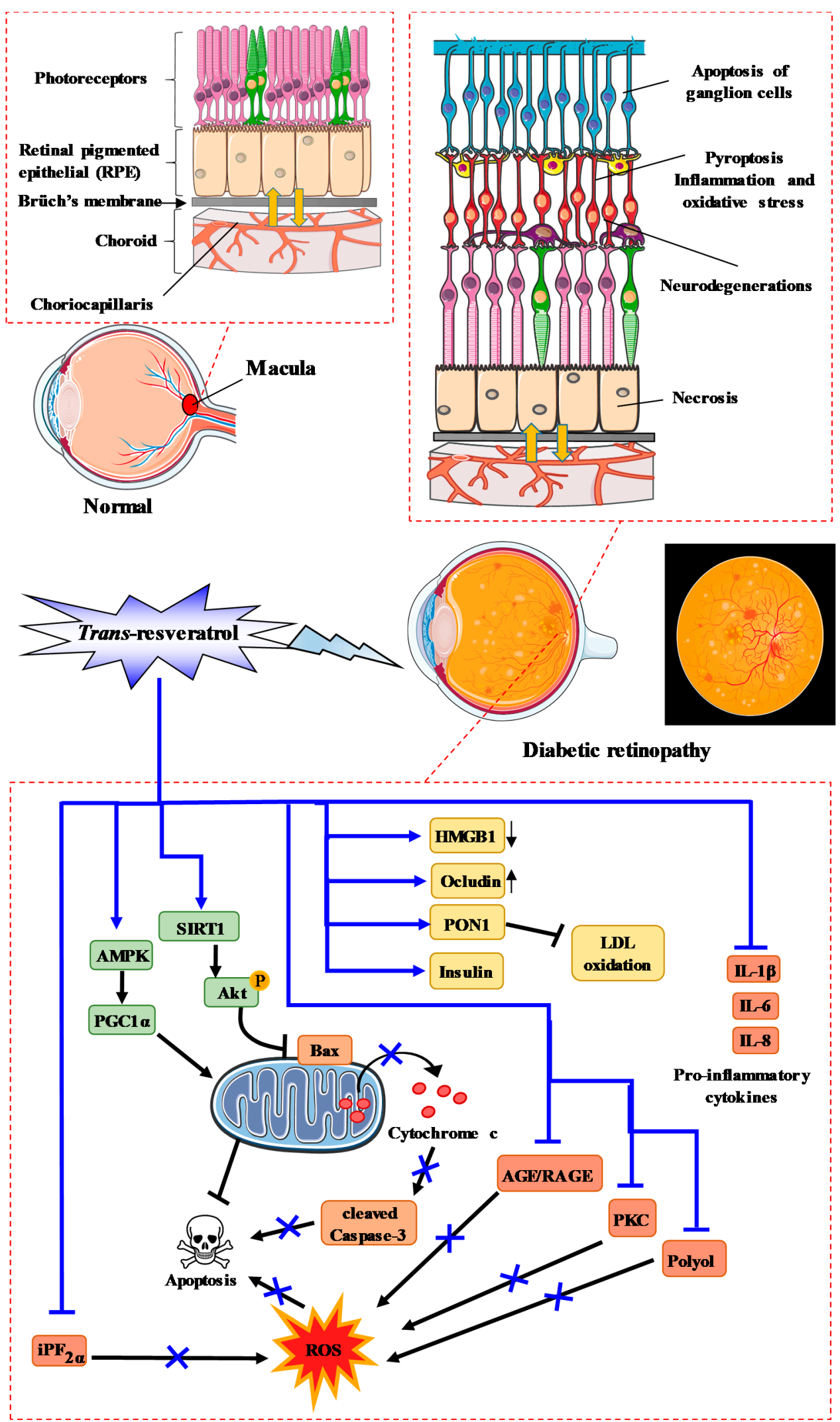

Figure 5. RSV action and process of diabetic retinopathy. RSV activates sirtuin-1 (Sirt-1), which leads to the phosphorylation of Akt and inhibits the mitochondrial apoptosis pathway. Furthermore, RSV stimulates mitochondrial activity through the AMPK-PGC1 $\alpha$ pathway, which reduces apoptosis. RSV also lowers ROS through the iPf $2 \alpha$, AGE/RAGE, PKC, and polyol pathways, and downregulates pro-inflammatory cytokines such as IL-1 $\beta$, IL-6, and IL-8. 
Very interestingly, these beneficial effects were inhibited by the miR-29b inhibitor [151]. RSV inhibited the high-glucose-induced decreases in glutamate uptake, glutamine synthase activity, glutamate transporters, and glutamine synthase expression in high-glucose-treated Müller cell cultures compared to controls [152]. Moreover, RSV (10 mg/g/day) alleviated hyperglycemia in diabetic rats and attenuated diabetes-induced decreases in the amplitude of a-wave in rod response, decreases in the amplitude of a- and b-waves in the cone and rod response, and decreases in amplitude of OP2 in oscillatory potentials [152].

Immune cells seem to be involved in the inflammatory process found in DR through the release of IL-17 by lymphocyte T helper 17 (Th17). Indeed, serum of patients with DR exhibit higher IL-17 expression than non-diabetic control groups [153,154]. Moreover, peripheral blood mononuclear cells (PBMCs) exhibited increased expression levels of IL-17 in the DR group of patients, whereas Sirt-1 protein expression decreased in the PBMCs of patients with DR [154]. Interestingly, RSV was able to reduce IL-17 secretion levels in PBMC cultures from patients with proliferative DR, as well as restore Sirt-1 expression in both genic and protein expression [154]. These results obtained on cultured PBMCs echo the results that we have been able to demonstrate directly on Th17 immune cells, where resveratrol was able to reduce the production of IL-17, as well as alter the process of differentiation of naive T lymphocytes into pro-inflammatory Th17 immune cells [155]. In addition, in numerous in vivo models, we have been able to show that resveratrol is able to decrease not only the secretion of IL-17, but also the key factors involved in lymphocyte differentiation. This process is associated with a highly significant decrease in angiogenesis by reducing VEGF-A secretion. This mechanism is dependent on the Sirt-1 protein, where the conditional invalidation of Sirt-1 in T CD4 cells demonstrated that this effect on the production of IL-17 and VEGF was under the control of the Sirt-1 protein and the nuclear transcriptional factor STAT3 [155].

\section{Vitreoretinopathy and RSV Action}

Proliferative vitreoretinopathy (PVR) is the main cause of failure following retinal detachment surgery. The membrane cells seen in PVR are of the pseudofibroblastic type, but they have several origins, in particular astrocytes and RPE cells. The importance of RPE cells in VRP likely stems from the access of RPE cells to the vitreous due to retinal invasion and the dispersion of viable RPE cells into the vitreous during cryopexy treatment of retinal tears. There are various key actors involved in the development of PVR, which is dependent on the migration and proliferation of RPE cells, glial cells, and inflammatory cells [156]. In this way, TGF- $\beta 2$-induced epithelial-to-mesenchymal transition (EMT), and EMT inhibition decreases collagen gel contraction and fibrotic membrane formation, resulting in the prevention of PVR. Moreover, numerous cytokines such as IL-1 $\beta$ and IL-6 are considered to be key factors in the development of PVR.

In a model of ARPE-19 cells, RSV suppressed the decrease of zona occludens-1 (ZO1 ) and caused an increase of alpha-smooth muscle actin expression in TGF- $\beta 2$-treated cells and increased vimentin expression [157]. Very interestingly, RSV decreased TGF$\beta 2$-induced wound closure and cell migration, as well as collagen gel contraction and the phosphorylation of Smad2 and Smad3 in TGF- $\beta 2$-treated ARPE-19 cells [157]. With regard to Smad protein, another study in RPE cells has shown that RSV induced EMT and inhibited TGF- $\beta 2$-induced EMT of RPE cells by deacetylation of Smad4 [158]. TGF- $\beta 2$ is not the only growth factor involved: platelet-derived growth factor (PDGF) has been shown to enhance the proliferation and migration of RPE cells in PVR. RSV was also able to inhibit PDGF-BB, an isoform of PDGF and PI3K/Akt, ERK, and p38 pathways, but had no effect on RPE cell adhesion to fibronectin $[63,159]$. 


\section{Corneal Infection and RSV Action}

Corneal infection represents a group of serious and blind ocular diseases. The cornea, in its normal condition, is highly resistant to microbial invasion. Nevertheless, pathogens may invade the cornea if epithelial integrity is breached. Corneal infection is a common ocular infection that can lead to ocular morbidity and blindness. These infections can be caused by several bacteria, virus, or fungi, with the common treatment being antibiotic drops.

Some studies have investigated the potential antibiotic action of RSV on corneal infection. An in vivo study revealed that RSV can reduce the cytotoxicity of Acanthamoeba castellanii on the HBMEC cell line [160]. Marino et al. showed that RSV can have a beneficial effect on Staphylococcus aureus-induced keratitis in an ex vivo culture model of rabbit cornea [161]. Indeed, this study demonstrated that RSV treatment can downregulate cell surface TLR2 on cells and reduce the expression of the interleukin-8 gene and, therefore, reduce the action of Staphylococcus aureus. In order to better understand the action of RSV on corneal infection, Tsai et al. investigated its antioxidant action on a human corneal epithelial cell line exposed to levofloxacin or moxifloxacin. They demonstrated that RSV not only increased cell survival, but also reduced intracellular accumulation of oxidative stress [162]. Unfortunately, the mechanism of RSV on corneal infection remains poorly understood, and further studies are required in order to gain deeper insight into the mechanism of RSV on corneal infection.

\section{Potential Epigenetic Action of RSV in AMD and Cataract Prevention}

RSV could also act by other mechanisms, particularly through sirtuins, which have recently been described as essential targets in various processes such as cellular stress resistance, genomic stability, tumorigenesis, and energy metabolism [8]. Sirt-1 is found in various organs and tissues regulating a variety of pathways such as glucose production in liver, fat mobilization and lipid metabolism in adipose tissue, as well as angiogenesis in blood vessels or other processes in the brain, pancreas, and intestine. Sirt-1 is expressed in almost all ocular tissues, including the cornea, lens (epithelial cells), iris, ciliary body, and retina. Particularly in the cornea, Sirt-1 is located in the corneal epithelial cells, keratocytes, and corneal endothelial cells. In the retina, Sirt-1 is found in the RPE, outer nuclear layer (ONL), inner nuclear layer (INL), and ganglion cell layer (GCL).

In eyes, Sirt- 1 seems to protect the retinal cells from DNA damage such as oxidative stress-related retinal damage, apoptotic retinal death, and anti-inflammation. In addition, the breakdown of Sirt- 1 causes retinal damage through multiple mechanisms. Thus, RSV, which is described as an agonist of sirtuins, could protect the eye by Sirt- 1 activation. In this way, Kubota et al. showed that oral RSV pretreatment at a dose of $50 \mathrm{mg} / \mathrm{kg}$ for 5 days reverses retinal Sirt- 1 activity to restore its basal activity in BALB/c mice exposed to 5000-lux white light for $3 \mathrm{~h}$ [163]. These events are associated with a significant decrease in the number of apoptotic cells in the ONL. Moreover, recent studies have shown that RSV inhibits hypoxia-inducible factor (HIF)- $1 \alpha$ accumulation and VEGF secretion induced by cobalt chloride (CoCl2) through Sirt-1 in human RPE cells [108,164]. In this way, RSV downregulated VEGF-R2 phosphorylation and activation induced by VEGF in endothelial cells via Sirt-1 and, thus, could contribute to reducing choroidal neovascularization. Furthermore, RSV restored the activity of DNA methyltransferases (DNMTs), which catalyze the methylation process, in ARPE-19 cells, and, more specifically, restored LINE-1 methylation in retinal cells under oxidative and inflammatory conditions [165]. These results are not surprising, partly since Sirt-1 regulates the activity of DNMTs, especially DNMT1 [166]. The overexpression of Sirt-1 is associated with an induction by RSV of AMPK phosphorylation and an overexpression of PGC-1 $\alpha$ protein [137]. Indeed, the beneficial effects of RSV were suppressed by inhibitors of AMPK and Sirt-1, as well as by treatment with PGC- $1 \alpha$ siRNA. This AMPK pathway is also demonstrated in a mice model of STZ-induced diabetes [167]. Nevertheless, Michan et al. showed that neither overexpression of Sirt-1 by a genetic approach (i.e., conditional Sirt-1 overexpression in retinal neurons or vessels by breeding Sirt-1 overexpressing flox mice with Nestin-Cre or 
Tie2-Cre mice, respectively) or by a pharmacological approach with Sirt-1 agonists (i.e., RSV) provides additional protection against retinopathy in mice [168]. In transformed retinal Müller (glial) cells in hyperglycemia-like conditions, RVS decreased acetylation of histone $\mathrm{H} 3$ and could thus prevent the inflammatory changes that contribute to various ocular diseases such as DR [169]. Further studies are needed to examine whether RSV could modulate epigenetic alterations in ocular diseases.

\section{New RSV Formulations and Clinical Trials}

\subsection{New Formulations of RSV}

Several formulations have been developed to efficiently deliver RSV in the eye, including nanoparticle complexation and lipid-based encapsulation. For instance, RSV-loaded polyethylene glycols (PEGs) modified chitosan (CS) nanoparticles (NPs) by an ionic gelation method that was developed and tested both in vitro and in vivo in a rabbit model of glaucoma [170,171]. Data showed that this formulation improved corneal permeation compared with RSV dispersion, and that NPs can evoke an initial burst of RSV release of $45 \%$, followed by a controlled release [165]. In vivo, the formulation was shown to efficiently reach the cornea and retinal choroid, and to significantly reduce IOP by $4.3 \pm 0.5 \mathrm{~mm} \mathrm{Hg}$ for up to $8 \mathrm{~h}$ in normotensive rabbits [170,171]. In a cellular model of AMD (ARPE-19 cells), it was also demonstrated that the use of RSV-loaded poly(lactic-co-glyolic acid) (PLGA) nanoparticles (optimized formulation with a particle size of $102.7 \mathrm{~nm}$ ) improved RSV cellular uptake and increased RSV-induced inhibition of VEGF expression [172]. Although not tested as yet in vivo, this RSV formulation, either alone or in combination with conventional anti-VEGF therapies, may be promising in reducing VEGF-induced neovascularization in an AMD context. In epithelial D407 cells, Rugină et al. [173] used a microencapsulated RSV formulation based on porous $\mathrm{CaCO}_{3}$ templates and polyelectrolyte layers covered by rhodamine 6G (Rh6G). Their so-called as-designed PMs-Rv-Rh6G microcapsules were internalized by D407 cells grown in normal and high glucose-induced inflammation conditions (to mimic DR), and reached the cell nucleus within $24 \mathrm{~h}$. This formulation bioavailability was correlated with the inhibition of the expression and secretion of VEGF as assessed by ELISA. Additionally, the use of RSV loaded into lipid-cyclodextrin-based nanoparticles also seems to increase RSV bioavailability and to potentiate RSV-induced ROS scavenging capacities compared to RSV alone [174]. Besides nanoparticles or delivery vehicles, the design of an RSV prodrug formulation has also emerged. For instance, Valdés-Sánchez et al. [175] developed an RSV prodrug, 3,4'-diglucosyl resveratrol (JC19), and tested its efficiency in an experimental mouse model (autosomal recessive RP.Rd10 mice). They injected JC19 subretinally on postnatal day 13, and showed, 15 days post-injection, that JC19 significantly delayed the loss of rod photoreceptors associated with the maintenance of rhodopsin expression and the preservation of their electrical responses to light stimuli. Mechanistically, the authors suggest that Sirt1 activation by JC19 could explain the beneficial effects of the formulation.

\section{2. $R S V$ and Clinical Trials}

Over the past decade, preclinical and clinical trials (Table 2) have shown that RSV could have a beneficial effect on health. Indeed, clinical trial has revealed that RSV supplementation in normal and healthy subjects can have antioxidant and anti-inflammatory properties in response to a high-fat, high-carbohydrate meal [176], which supports the fact that RSV could be used clinically in humans without toxicity. 
Table 2. Clinical trials with resveratrol with ocular measurements.

\begin{tabular}{|c|c|c|c|c|c|c|c|}
\hline Author & Year & Region & Study Design & $\begin{array}{c}\text { No. of Participants per Group } \\
\text { Age (Mean } \pm \text { SD) }\end{array}$ & $\begin{array}{c}\text { Dose/Frequency/Duration/ } \\
\text { Follow-Up }\end{array}$ & Effects & Ref \\
\hline Lin, C.T. et al. & 2016 & China & $\begin{array}{c}\text { Randomized } \\
\text { double-blinded trial }\end{array}$ & $n=72$ & $\begin{array}{c}\text { (150 or } 450 \mathrm{mg} / \mathrm{d}) \text { trans-RSV or } \\
\text { placebo during } 12 \text {-week } \\
\text { treatment } \\
\text { Visits were scheduled at } 0,4,8 \\
\text { and } 12 \text { weeks after treatment }\end{array}$ & $\begin{array}{l}\text { Appearance rates of VEGF, Flk-1, } \\
\text { and Ang-2 were more significantly } \\
\text { reduced in the high-dose group } \\
\text { versus the placebo group, but not } \\
\text { in the low-dose group. }\end{array}$ & [177] \\
\hline Wang S. et al. & 2016 & China & $\begin{array}{l}\text { Randomized and } \\
\text { divided into two } \\
\text { groups matched by } \\
\text { age and gender }\end{array}$ & $\begin{array}{l}34 \text { participants randomly divided into two groups } \\
\text { by age and gender matched, } 11 \text { women and seven } \\
\text { men with a mean age of } 25.44 \pm 1.46 \text { years } \\
\text { (age range, } 23-29 \text { years) for the study group; eight } \\
\text { women and eight men aged between } 23 \text { and } \\
28 \text { years with a mean age of } 24.88 \pm 1.26 \text { for the } \\
\text { control group. }\end{array}$ & $\begin{array}{l}\text { Longenivex ( } 100 \mathrm{mg} \text { of } \\
\text { trans-RSV per capsule) } \\
\text { against placebo } \\
\text { All OCT scans were performed } \\
\text { at the same time of day (between } \\
\text { 9:00 a.m. and 12:00 p.m.). }\end{array}$ & $\begin{array}{l}\text { A statistical increase in choroidal } \\
\text { thickness (by EDI-OCT) } 1 \mathrm{~h} \text { after } \\
\text { Longevinex ingestion compared } \\
\text { with baseline measurements. }\end{array}$ & [180] \\
\hline Richer S. et al. & 2014 & USA & & $\begin{array}{c}n=3 \text { (two males and one female): } \\
\text { Case 1: } 64 \text { y/o Caucasian with suspected glaucoma } \\
\text { and photophobia, atrophic AMD, and diabetes } \\
\text { with declining visual function in the right eye, had } \\
\text { been on L/RV for } 2.5 \text { years and was maintaining } \\
\text { visual function; } \\
\text { Case 2: } 89 \text { y/o Caucasian with chronic kidney } \\
\text { disease and cataracts, had been on L/RV for } \\
3 \text { years maintaining his visual function } \\
\text { requirements to retain his driver's license; } \\
\text { Case 3: } 67 \text { y/o Caucasian with bilateral polypoidal } \\
\text { choroidal vasculopathy (PCV), a } \\
\text { treatment-resistant AMD variant, worse in the } \\
\text { right eye. Improved retinal/choroid structure } \\
\text { was observed. }\end{array}$ & $\begin{array}{c}\text { Cases } 1,2: 2,5 \text { years } \\
\text { Case 3: } 2 \text { years with Longevinex } \\
\text { containing } 100 \mathrm{mg} \text { of RSV) }\end{array}$ & $\begin{array}{l}\text { Broad bilateral improvements in } \\
\text { retina and choroid structure and } \\
\text { function, visual acuity, contrast } \\
\text { sensitivity, and glare recovery } \\
\text { over a long time period, contrary } \\
\text { to what might be expected due to } \\
\text { aging and the natural progression } \\
\text { of the patient's pathophysiology. } \\
\text { No side effects were observed. }\end{array}$ & [179] \\
\hline
\end{tabular}


Table 2. Clinical trials with resveratrol with ocular measurements.

\begin{tabular}{|c|c|c|c|c|c|c|c|}
\hline Author & Year & Region & Study Design & $\begin{array}{c}\text { No. of Participants per Group } \\
\text { Age (Mean } \pm \text { SD) }\end{array}$ & $\begin{array}{c}\text { Dose/Frequency/Duration/ } \\
\text { Follow-Up }\end{array}$ & Effects & Ref \\
\hline Richer S. et al. & 2013 & USA & & $\begin{array}{c}n=3 \text { (two males and one female): } \\
\text { Case 1: } 86 \text { y/o morbidly obese male and } \\
\text { advanced AMD; } \\
\text { Case 2: } 88 \text { y/o female with bilateral wet AMD; } \\
\text { Case 3: } 75 \text { y/o male with diabetes and dry AMD } \\
\text { who developed wet AMD. }\end{array}$ & $\begin{array}{l}100 \mathrm{mg} \text { micronized/micro- } \\
\text { encapsulated trans-RSV in } \\
\text { Longevinex formulations. }\end{array}$ & $\begin{array}{c}\text { Case } 1 \text { showed a Snellen visual } \\
\text { acuity improvement by seven } \\
\text { lines at } 6 \text { weeks and better IR } \\
\text { choroidal circulatory images } \\
\text { during the same period. } \\
\text { Case } 2 \text { showed bilateral } \\
\text { improvement in visual function } \\
\text { and near resolution of retinal fluid } \\
\text { after } 2 \text { weeks. } \\
\text { Case } 3 \text { reported better vision in } \\
5 \text { days with L/RV, and objective } \\
\text { retinal and visual restoration } \\
\text { similar to anti-VEGF therapy } \\
\text { wasobserved after } 52 \text { days of } \\
\text { treatment }\end{array}$ & [178] \\
\hline
\end{tabular}


Preclinical studies have shown that RSV has beneficial effects in ocular diseases, particularly AMD, glaucoma, cataract, DR, and vitreoretinopathy. Indeed, in vivo and in vitro studies have shown the anti-angiogenic potential of RSV in AMD [71] and DR [106]. One randomized and double-blinded clinical trial including 72 patients showed that supplementation with trans-resveratrol can lower VEGF levels in peritoneal effluent [177], thereby supporting the notion that RSV could be effective at reducing neovascularization in patients. Another clinical trial performed in the USA in octogenarians also showed that oral administration of Longevinex ${ }^{\circledR}$, which is a combination of RSV with quercetin, ferulic acid together with vitamin D3 and a cooper/iron/calcium binding molecule called IP6 (inositol hexaphosphate), could improve retinal structure and visual function [178] as well as reduce neovascularization [179]. Moreover, a clinical trial on 19 type 2 diabetic patients supplemented with RSV revealed that it can not only be used to reduce oxidative stress and activate the AKT pathway, but also to improve insulin sensitivity [91]. Indeed, preclinical trials have shown that RSV can restore insulin levels in vitro.

\subsection{RSV and Association with Other Therapeutics}

Much evidence has been provided with regard to the bioactivities of RSV alone, both in vitro and in vivo. Nevertheless, RSV could also be useful in combination with conventional therapies. Indeed, in a cancer context, it was shown that RSV can act as a therapeutic adjuvant and is able to potentiate the efficacy of chemotherapies. Some studies have also shown the adjuvant potential of RSV in ocular diseases. For instance, in an experimental model of glaucoma, treatment with RSV either alone or in combination with riluzole significantly delayed RGC loss [181]. Very interestingly, Subramani et al. showed that RSV was able to reverse the adverse effects of bevacizumab on cultured ARPE-19 cells [182]. Indeed, numerous patients treated with anti-VEGF therapies show clinical complications due to repeated intravitreal injections $[183,184]$. In the presence of RSV, Notch signaling gets activated. This activation, along with dephosphorylation of Erk 1/2 and MEK, has been shown to be a major driver of the functional restoration of RPE cells treated with a RSV/bevacizumab combination compared to those treated with bevacizumab alone [182].

\section{Safety of RSV}

Concerning the toxicity of RSV, various studies have shown that RSV does not exhibit cytotoxicity in animal models and normal cells at the concentrations usually used in vitro (up to $100 \mu \mathrm{M}$ ) or in vivo (up to $500 \mathrm{mg} / \mathrm{kg} /$ day; see Table III) [185-188]. Moreover, some clinical studies have shown that RSV is safe in humans at various doses. Indeed, after daily RSV administration $(0.5,1.0,2.5$, or $5.0 \mathrm{~g})$ for 29 days in 40 healthy volunteers, no significant adverse effects were observed, only mild to moderate gastrointestinal symptoms at 2.5 and $5.0 \mathrm{~g}$ RSV [189]. Other reports on trials of RSV in humans after single [190,191] or multiple daily doses of up to $600 \mathrm{mg} / \mathrm{d}$ administered over 2 or 3 days [192,193] show that RSV is safe under the tested conditions. Recent clinical studies have shown that patients with confirmed colorectal cancer present high levels of RSV metabolites, especially RSV-3-Osulphate, RSV-3-O-glucuronide, and RSV-4-O-glucuronide, accumulated in the colorectum, and we have recently shown that these metabolites have anticarcinogenic properties. Thus, this poses the question as to whether RSV or RSV metabolites could be accumulated in eyes and ocular tissues and whether it is the aglycone molecule or its metabolites that are active. In fact, Wang et al. measured trans-RSV and its main metabolites in human eyes in patients with rhegmatogenous retinal detachment that were orally supplemented with Longevinex ${ }^{\circledR}$ (containing $100 \mathrm{mg}$ of trans-RSV; one capsule daily for a total of three doses prior to surgical tissue resection) [194]. HPLC/MS-MS was performed to quantify transRSV, RSV-3-O-sulfate, RSV-3-O-glucuronide, and RSV-4'-O-glucuronide on tissue samples. The investigators showed that RSV and its main metabolites were detectable in conjunctiva, aqueous humor, and vitreous humor (i.e., $17.19 \pm 15.32 \mathrm{nmol} / \mathrm{g}$ RSV in conjunctiva and $62.95 \pm 41.97 \mathrm{nmol} / \mathrm{L}$ RSV-3-O-sulfate in aqueous humor). These data suggest that RSV 
and its main metabolites can be found in human eyes after supplementation and could potentially participate at the tissue level in the treatment of ocular diseases.

\section{Conclusions}

There is compelling evidence that RSV can act on various pathologies in vivo such as coronary heart damage, cancer, and degenerative disease, by affecting various pathways. Along these pathways, RSV is able to act on common targets such as reactive oxygen species, lipids mediators, apoptosis, pro-inflammatory mediators, and angiogenesis. Through these mechanisms, RSV could prevent age-related ocular diseases (i.e., AMD, glaucoma, cataract, and DR) and could protect eyes against environmental factors (such as diabetes, hypertension, stress, UV light, acrolein found in cigarette smoke, and air pollution).

Finally, through its pleiotropic properties/mechanisms of action, RSV could constitute a good candidate to prevent ocular diseases and may provide a novel strategy to enhance the efficacy of therapy currently used. More preclinical studies are required to provide further insights into RSV's potential adjuvant activity.

\section{Methods}

For this review, a systematic search of PubMed (https:/ / pubmed.ncbi.nlm.nih.gov/) was conducted to identify studies on RSV in ocular cells, experimental animals, or humans in relation to ocular diseases up to December 2020. The search term "resveratrol" was used in combination with "ocular diseases," "eye diseases," "retinal cells," "oxidative stress," "reactive oxygen species" (ROS), "age-related macular degeneration," "AMD," "glaucoma," "cataract," "diabetic retinopathy," "corneal infection," "vitreoretinopathy," "epigenetic," and "clinical trials." The search was limited to English-language studies.

Author Contributions: Conceptualization, D.D. and V.A. writing—original draft preparation, D.D.; writing-review and editing, C.C., F.C. and J.X.; visualization, C.C. and J.X.; supervision, D.D.; funding acquisition, D.D. All authors have read and agreed to the published version of the manuscript.

Funding: This work was supported by grants from the ANRT №2016/0003, by a French Government grant managed by the French National Research Agency under the program "Investissements d'Avenir," reference ANR-11-LABX-0021, the Conseil Régional Bourgogne, Franche-Comte, the FEDER (European Funding for Regional Economic Development), and the "Bureau Interprofessionnel des Vins de Bourgogne" (BIVB). The authors thank Miss Isabella Athanassiou for valuable English corrections.

Conflicts of Interest: The authors declare that there are no conflicts of interest.

\section{References}

1. Pascolini, D.; Mariotti, S.P. Global estimates of visual impairment: 2010. Br. J. Ophthalmol. 2012, 96, 614-618. [CrossRef] [PubMed]

2. Ghiringhelli, F.; Rebe, C.; Hichami, A.; Delmas, D. Immunomodulation and anti-inflammatory roles of polyphenols as anticancer agents. Anticancer Agents Med. Chem. 2012, 12, 852-873. [CrossRef]

3. Afaq, F.; Adhami, V.M.; Ahmad, N.; Mukhtar, H. Botanical antioxidants for chemoprevention of photocarcinogenesis. Front. Biosci. 2002, 7, d784-d792. [CrossRef] [PubMed]

4. Delmas, D.; Xiao, J. Natural Polyphenols Properties: Chemopreventive and Chemosensitizing Activities. Anticancer Agents Med. Chem. 2012, 12, 835. [CrossRef]

5. Delmas, D.; Jannin, B.; Latruffe, N. Resveratrol: Preventing properties against vascular alterations and ageing. Mol. Nutr. Food Res. 2005, 49, 377-395. [CrossRef] [PubMed]

6. Delmas, D.; Limagne, E.; Ghiringhelli, F.; Aires, V. Immune Th17 lymphocytes play a critical role in the multiple beneficial properties of resveratrol. Food. Chem. Toxicol. 2020, 137, 111091. [CrossRef]

7. Delmas, D.; Solary, E.; Latruffe, N. Resveratrol, a phytochemical inducer of multiple cell death pathways: Apoptosis, autophagy and mitotic catastrophe. Curr. Med. Chem. 2011, 18, 1100-1121. [CrossRef] [PubMed]

8. Baur, J.A.; Sinclair, D.A. Therapeutic potential of resveratrol: The in vivo evidence. Nat. Rev. Drug. Discov. 2006, 5, 493-506. [CrossRef] [PubMed]

9. Takaoka, M. Of the phenolic substances of white hellebore (Veratrum grandiflorum Loes. fil.). J. Fac. Sci. Hokkaido Imp. Univ. 1940, 3, 1-16. [CrossRef] 
10. Lanz, T.; Tropf, S.; Marner, F.J.; Schroder, J.; Schroder, G. The role of cysteines in polyketide synthases. Site-directed mutagenesis of resveratrol and chalcone synthases, two key enzymes in different plant-specific pathways. J. Biol. Chem. 1991, 266, 9971-9976. [CrossRef]

11. Hanawa, F.; Tahara, S.; Mizutani, J. Antifungal stress compounds from Veratrum grandiflorum leaves treated with cupric chloride. Phytochemistry 1992, 31, 3005-3007. [CrossRef]

12. Chung, M.I.; Teng, C.M.; Cheng, K.L.; Ko, F.N.; Lin, C.N. An antiplatelet principle of Veratrum formosanum. Planta Med. 1992, 58, 274-276. [CrossRef] [PubMed]

13. Nomura, S.; Kanagawa, H.; Makimoto, A. Chemical constituents of polygonaceous plants. I. Studies on the components of Ko-jo-kon. (Polygonum cuspitadum SIEB et ZUCC). Yakugaku Zasshi 1963, 83, 988-990. [CrossRef]

14. Kubo, M.; Kimura, Y.; Shin, H.; Haneda, T.; Tani, T.; Namba, K. Studies on the antifungal substance of crude drug (II). On the roots of Polygonum cuspidatum Sieb. et Zucc. (Polygonaceae). Shoyakugaku Zashi 1981, 35, 58-61.

15. Hathway, D.E.; Seakins, J.W. Hydroxystilbenes of Eucalyptus wandoo. Biochem. J. 1959, 72, 369-374. [CrossRef] [PubMed]

16. Hillis, W.; Hart, J.; Yazaki, Y. Polyphenols of Eucalyptus sideroxylon wood. Phytochemistry 1974, 13, 1591-1595. [CrossRef]

17. Rolfs, C.; Kindl, H. Stilbene synthase and chalcone synthase. Two different constitutive enzymes in cultured cells of Picea excels. Plant Physiol. 1974, 75, 489-492. [CrossRef]

18. Anjaneyulu, A.; Reddy, A.; Reddy, D.; Ward, R.; Adhikesavalu, D.; Cameron, T. Prachin: A new dibenzo (2,3-6,7) oxepin derivative from Bauhinia racemosa lamk. Tetrahedon 1984, 40, 4245-4252. [CrossRef]

19. Kumar, R.; Jyostna, D.; Krupadanam, G.; Srimannarayana, G. Phenanthrene and stilbenes from Pterolobium hexapetallum. Phytochemistry 1988, 27, 3625-3626. [CrossRef]

20. Ingham, J. 3,5,4'-Trihydroxystilbene as aphytoalexin from groundnuts (Arachis hypogaea). Phytochemistry 1976, 15, 1791-1793. [CrossRef]

21. Rolfs, C.; Fritzemeier, K.; Kindl, H. Cultured cells of arachis hypogaea susceptible to induction of stilbene synthase (resveratrolforming). Plant Cell Rep. 1981, 1, 83-85. [CrossRef] [PubMed]

22. Fritzemeier, K.; Rolfs, C.; Pfau, J.; Kindl, H. Action of ultraviolet-C on stilbene formation in callus of Arachis hypogaea. Planta 1983, 159, 25-29. [CrossRef] [PubMed]

23. Schoppner, A.; Kindl, H. Purification and properties of a stilbene synthase from induced cell suspension cultures of peanut. $J$. Biol. Chem. 1984, 259, 6806-6811. [CrossRef]

24. Ibern-Gomez, M.; Roig-Perez, S.; Lamuela-Raventos, R.M.; de la Torre-Boronat, M.C. Resveratrol and piceid levels in natural and blended peanut butters. J. Agric. Food Chem. 2000, 48, 6352-6354. [CrossRef]

25. Langcake, P.; Pryce, R.J. A new class of phytoalexins from grapevines. Experientia 1977, 33, 151-152. [CrossRef]

26. Langcake, P.; Cornford, C.; Pryce, R. Identification of pterostilbene as a phytoalexin from Vitis vinifera leaves. Phytochemistry 1979, 66, 1025-1027. [CrossRef]

27. Langcake, P.; Pryce, R. The production of resveratrol and the viniferins by grapevines in response to ultra-violet irradiation. Phytochemistry 1977, 16, 1193-1196. [CrossRef]

28. Jeandet, P.; Bessis, R.; Maume, B.; Sbaghi, M. Analysis of resveratrol in selected California wines by a new HPLC method. J. Wine Res. 1993, 4, 79-85. [CrossRef]

29. Hoos, G.; Blaich, R. Metabolism of stilbene phytoalexins in grapevines: Oxidation of resveratrol in single cell culture. VITIS J. Grapevine Res. 1988, 27, 1-12.

30. Jeandet, P.; Bessis, R.; Sbaghi, M.; Meunier, P. Occurence of a resveratrol- $\beta$-D-glucoside in wine. VITIS J. Grapevine Res. 1994, 33, 183-184.

31. Waterhouse, A.; Lamuele-Raventos, R. The occurence of piceid, a stilbene glucoside in grape berries. Phytochemistry 1994, 37, 571-573. [CrossRef]

32. Goldberg, D.; Karumanchiri, A.; Diamandis, E.; Soleas, G. The assay of resveratrol glycosides and isomers in wine by directinjection HPLC. J. Chromatogr. A 1995, 708, 89-98. [CrossRef]

33. Callemien, D.; Jerkovic, V.; Rozenberg, R.; Collin, S. Hop as an Interesting Source of Resveratrol for Brewers: Optimization of the Extraction and Quantitative Study by Liquid Chromatography/Atmospheric Pressure Chemical Ionization Tandem Mass Spectrometry. J. Agric. Food Chem. 2005, 53, 424-429. [CrossRef] [PubMed]

34. Burns, J.; Yokota, T.; Ashihara, H.; Lean, M.E.; Crozier, A. Plant foods and herbal sources of resveratrol. J. Agric. Food Chem. 2002, 50, 3337-3340. [CrossRef]

35. Careri, M.; Corradini, C.; Elviri, L.; Nicoletti, I.; Zagnoni, I. Direct HPLC analysis of quercetin and trans-resveratrol in red wine, grape, and winemaking byproducts. J. Agric. Food Chem. 2003, 51, 5226-5231. [CrossRef] [PubMed]

36. Lyons, M.M.; Yu, C.; Toma, R.B.; Cho, S.Y.; Reiboldt, W.; Lee, J.; van Breemen, R.B. Resveratrol in raw and baked blueberries and bilberries. J. Agric. Food Chem. 2003, 51, 5867-5870. [CrossRef]

37. Kris-Etherton, P.M.; Keen, C.L. Evidence that the antioxidant flavonoids in tea and cocoa are beneficial for cardiovascular health Curr. Opin Lipidol. 2002, 13, 41-49. [CrossRef]

38. Jang, M.; Cai, L.; Udeani, G.O.; Slowing, K.V.; Thomas, C.F.; Beecher, C.W.; Fong, H.H.; Farnsworth, N.R.; Kinghorn, A.D.; Mehta, R.G.; et al. Cancer chemopreventive activity of resveratrol, a natural product derived from grapes. Science 1997, 275, 218-220. [CrossRef] 
39. Belguendouz, L.; Fremont, L.; Linard, A. Resveratrol inhibits metal ion-dependent and independent peroxidation of porcine low-density lipoproteins. Biochem. Pharm. 1997, 53, 1347-1355. [CrossRef]

40. Fremont, L.; Belguendouz, L.; Delpal, S. Antioxidant activity of resveratrol and alcohol-free wine polyphenols related to LDL oxidation and polyunsaturated fatty acids. Life Sci. 1999, 64, 2511-2521. [CrossRef]

41. Fauconneau, B.; Waffo-Teguo, P.; Huguet, F.; Barrier, L.; Decendit, A.; Merillon, J.M. Comparative study of radical scavenger and antioxidant properties of phenolic compounds from Vitis vinifera cell cultures using in vitro tests. Life Sci. 1997, 61, $2103-2110$. [CrossRef]

42. Orallo, F.; Alvarez, E.; Camina, M.; Leiro, J.M.; Gomez, E.; Fernandez, P. The possible implication of trans-Resveratrol in the cardioprotective effects of long-term moderate wine consumption. Mol. Pharm. 2002, 61, 294-302. [CrossRef]

43. Leiro, J.; Alvarez, E.; Arranz, J.A.; Laguna, R.; Uriarte, E.; Orallo, F. Effects of cis-resveratrol on inflammatory murine macrophages: Antioxidant activity and down-regulation of inflammatory genes. J. Leukoc Biol. 2004, 75, 1156-1165. [CrossRef]

44. Shigematsu, S.; Ishida, S.; Hara, M.; Takahashi, N.; Yoshimatsu, H.; Sakata, T.; Korthuis, R.J. Resveratrol, a red wine constituent polyphenol, prevents superoxide-dependent inflammatory responses induced by ischemia/reperfusion, platelet-activating factor, or oxidants. Free Radic. Biol. Med. 2003, 34, 810-817. [CrossRef]

45. Zhong, M.; Cheng, G.F.; Wang, W.J.; Guo, Y.; Zhu, X.Y.; Zhang, J.T. Inhibitory effect of resveratrol on interleukin 6 release by stimulated peritoneal macrophages of mice. Phytomedicine 1999, 6, 79-84. [CrossRef]

46. Feng, Y.H.; Zou, J.P.; Li, X.Y. Effects of resveratrol and ethanol on production of pro-inflammatory factors from endotoxin activated murine macrophages. Acta Pharm. Sin. 2002, 23, 1002-1006.

47. Pace-Asciak, C.R.; Rounova, O.; Hahn, S.E.; Diamandis, E.P.; Goldberg, D.M. Wines and grape juices as modulators of platelet aggregation in healthy human subjects. Clin. Chim. Acta 1996, 246, 163-182. [CrossRef]

48. Olas, B.; Wachowicz, B.; Stochmal, A.; Oleszek, W. Anti-platelet effects of different phenolic compounds from Yucca schidigera Roezl. bark. Platelets 2002, 13, 167-173. [CrossRef]

49. Bertelli, A.A.; Giovannini, L.; Giannessi, D.; Migliori, M.; Bernini, W.; Fregoni, M.; Bertelli, A. Antiplatelet activity of synthetic and natural resveratrol in red wine. Int. J. Tissue React. 1995, 17, 1-3.

50. Delmas, D.; Lancon, A.; Colin, D.; Jannin, B.; Latruffe, N. Resveratrol as a chemopreventive agent: A promising molecule for fighting cancer. Curr. Drug. Targets 2006, 7, 423-442. [CrossRef]

51. Han, L.; Zhou, R.; Niu, J.; McNutt, M.A.; Wang, P.; Tong, T. SIRT1 is regulated by a PPAR\{gamma\}-SIRT1 negative feedback loop associated with senescence. Nucleic Acids Res. 2010, 38, 7458-7471. [CrossRef]

52. Khan, R.S.; Fonseca-Kelly, Z.; Callinan, C.; Zuo, L.; Sachdeva, M.M.; Shindler, K.S. SIRT1 activating compounds reduce oxidative stress and prevent cell death in neuronal cells. Front. Cell Neurosci. 2012, 6, 63. [CrossRef]

53. Klein, R.; Peto, T.; Bird, A.; Vannewkirk, M.R. The epidemiology of age-related macular degeneration. Am. J. Ophthalmol. 2004, 137, 486-495. [CrossRef]

54. AREDS. Risk factors associated with age-related macular degeneration. A case-control study in the age-related eye disease study: Age-Related Eye Disease Study Report Number 3. Ophthalmology 2000, 107, 2224-2232. [CrossRef]

55. Seddon, J.M.; Willett, W.C.; Speizer, F.E.; Hankinson, S.E. A prospective study of cigarette smoking and age-related macular degeneration in women. JAMA 1996, 276, 1141-1146. [CrossRef]

56. Cackett, P.; Yeo, I.; Cheung, C.M.; Vithana, E.N.; Wong, D.; Tay, W.T.; Tai, E.S.; Aung, T.; Wong, T.Y. Relationship of smoking and cardiovascular risk factors with polypoidal choroidal vasculopathy and age-related macular degeneration in Chinese persons. Ophthalmology 2011, 118, 846-852. [CrossRef]

57. Seddon, J.M.; George, S.; Rosner, B. Cigarette smoking, fish consumption, omega-3 fatty acid intake, and associations with age-related macular degeneration: The US Twin Study of Age-Related Macular Degeneration. Arch. Ophthalmol. 2006, 124, 995-1001. [CrossRef]

58. Seddon, J.M.; Cote, J.; Davis, N.; Rosner, B. Progression of age-related macular degeneration: Association with body mass index, waist circumference, and waist-hip ratio. Arch. Ophthalmol. 2003, 121, 785-792. [CrossRef]

59. Chen, Y.; Bedell, M.; Zhang, K. Age-related macular degeneration: Genetic and environmental factors of disease. Mol. Interv. 2010, 10, 271-281. [CrossRef]

60. Jarrett, S.G.; Boulton, M.E. Consequences of oxidative stress in age-related macular degeneration. Mol. Asp. Med. 2012, 33, 399-417. [CrossRef]

61. Cai, J.; Nelson, K.C.; Wu, M.; Sternberg, P., Jr.; Jones, D.P. Oxidative damage and protection of the RPE. Prog. Retin. Eye Res. 2000, 19, 205-221. [CrossRef]

62. Age-Related Eye Disease Study Research Group. A randomized, placebo-controlled, clinical trial of high-dose supplementation with vitamins $\mathrm{C}$ and $\mathrm{E}$, beta carotene, and zinc for age-related macular degeneration and vision loss: AREDS report no. 8. Arch. Ophthalmol. 2001, 119, 1417-1436. [CrossRef]

63. King, R.E.; Kent, K.D.; Bomser, J.A. Resveratrol reduces oxidation and proliferation of human retinal pigment epithelial cells via extracellular signal-regulated kinase inhibition. Chem. Biol. Interact 2005, 151, 143-149. [CrossRef]

64. Yang, Y.; Wu, Z.Z.; Cheng, Y.L.; Lin, W.; Qu, C. Resveratrol protects against oxidative damage of retinal pigment epithelium cells by modulating SOD/MDA activity and activating Bcl-2 expression. Eur. Rev. Med. Pharm. Sci 2019, 23, 378-388. [CrossRef]

65. Sheu, S.J.; Liu, N.C.; Chen, J.L. Resveratrol protects human retinal pigment epithelial cells from acrolein-induced damage. J. Ocul. Pharm. 2010, 26, 231-236. [CrossRef] 
66. Mimura, T.; Kaji, Y.; Noma, H.; Funatsu, H.; Okamoto, S. The role of SIRT1 in ocular aging. Exp. Eye Res. 2013, 116C, 17-26. [CrossRef]

67. Bhattarai, N.; Korhonen, E.; Toppila, M.; Koskela, A.; Kaarniranta, K.; Mysore, Y.; Kauppinen, A. Resvega Alleviates Hydroquinone-Induced Oxidative Stress in ARPE-19 Cells. Int. J. Mol. Sci. 2020, 21, 2066. [CrossRef]

68. Neal, S.E.; Buehne, K.L.; Besley, N.A.; Yang, P.; Silinski, P.; Hong, J.; Ryde, I.T.; Meyer, J.N.; Jaffe, G.J. Resveratrol Protects Against Hydroquinone-Induced Oxidative Threat in Retinal Pigment Epithelial Cells. Investig. Ophthalmol. Vis. Sci. 2020, 61, 32. [CrossRef]

69. Sheu, S.J.; Liu, N.C.; Ou, C.C.; Bee, Y.S.; Chen, S.C.; Lin, H.C.; Chan, J.Y. Resveratrol stimulates mitochondrial bioenergetics to protect retinal pigment epithelial cells from oxidative damage. Investig. Ophthalmol. Vis. Sci. 2013, 54, 6426-6438. [CrossRef]

70. Chan, C.M.; Huang, C.H.; Li, H.J.; Hsiao, C.Y.; Su, C.C.; Lee, P.L.; Hung, C.F. Protective effects of resveratrol against UVA-induced damage in ARPE19 cells. Int. J. Mol. Sci. 2015, 16, 5789-5802. [CrossRef]

71. Dugas, B.; Charbonnier, S.; Baarine, M.; Ragot, K.; Delmas, D.; Menetrier, F.; Lherminier, J.; Malvitte, L.; Khalfaoui, T.; Bron, A.; et al. Effects of oxysterols on cell viability, inflammatory cytokines, VEGF, and reactive oxygen species production on human retinal cells: Cytoprotective effects and prevention of VEGF secretion by resveratrol. Eur. J. Nutr. 2010, 49, 435-446. [CrossRef]

72. Vayssiere, J.L.; Petit, P.X.; Risler, Y.; Mignotte, B. Commitment to apoptosis is associated with changes in mitochondrial biogenesis and activity in cell lines conditionally immortalized with simian virus 40. Proc. Natl. Acad. Sci. USA 1994, 91, 11752-11756. [CrossRef]

73. Zamzami, N.; Marchetti, P.; Castedo, M.; Zanin, C.; Vayssiere, J.L.; Petit, P.X.; Kroemer, G. Reduction in mitochondrial potential constitutes an early irreversible step of programmed lymphocyte death in vivo. J. Exp. Med. 1995, 181, 1661-1672. [CrossRef]

74. Wallace, D.C. Mitochondrial diseases in man and mouse. Science 1999, 283, 1482-1488. [CrossRef]

75. Zini, R.; Morin, C.; Bertelli, A.; Bertelli, A.A.; Tillement, J.P. Effects of resveratrol on the rat brain respiratory chain. Drugs Exp. Clin. Res. 1999, 25, 87-97.

76. Yen, G.C.; Duh, P.D.; Lin, C.W. Effects of resveratrol and 4-hexylresorcinol on hydrogen peroxide-induced oxidative DNA damage in human lymphocytes. Free Radic Res. 2003, 37, 509-514. [CrossRef]

77. Kampa, M.; Hatzoglou, A.; Notas, G.; Damianaki, A.; Bakogeorgou, E.; Gemetzi, C.; Kouroumalis, E.; Martin, P.M.; Castanas, E. Wine antioxidant polyphenols inhibit the proliferation of human prostate cancer cell lines. Nutr. Cancer 2000, 37, $223-233$. [CrossRef]

78. Sainz, R.M.; Mayo, J.C.; Tan, D.X.; Lopez-Burillo, S.; Natarajan, M.; Reiter, R.J. Antioxidant activity of melatonin in Chinese hamster ovarian cells: Changes in cellular proliferation and differentiation. Biochem. Biophys. Res. Commun. 2003, 302, 625-634. [CrossRef]

79. Lopez-Burillo, S.; Tan, D.X.; Mayo, J.C.; Sainz, R.M.; Manchester, L.C.; Reiter, R.J. Melatonin, xanthurenic acid, resveratrol, EGCG, vitamin $C$ and alpha-lipoic acid differentially reduce oxidative DNA damage induced by Fenton reagents: A study of their individual and synergistic actions. J. Pineal Res. 2003, 34, 269-277. [CrossRef]

80. Kasdallah-Grissa, A.; Mornagui, B.; Aouani, E.; Hammami, M.; El May, M.; Gharbi, N.; Kamoun, A.; El-Fazaa, S. Resveratrol, a red wine polyphenol, attenuates ethanol-induced oxidative stress in rat liver. Life Sci. 2006, 80, 1033-1039. [CrossRef]

81. Hu, Y.; Rahlfs, S.; Mersch-Sundermann, V.; Becker, K. Resveratrol modulates mRNA transcripts of genes related to redox metabolism and cell proliferation in non-small-cell lung carcinoma cells. Biol. Chem. 2007, 388, 207-219. [CrossRef]

82. Sengottuvelan, M.; Deeptha, K.; Nalini, N. Resveratrol ameliorates DNA damage, prooxidant and antioxidant imbalance in 1,2-dimethylhydrazine induced rat colon carcinogenesis. Chem. Biol. Interact 2009, 181, 193-201. [CrossRef]

83. Sengottuvelan, M.; Senthilkumar, R.; Nalini, N. Modulatory influence of dietary resveratrol during different phases of 1,2dimethylhydrazine induced mucosal lipid-peroxidation, antioxidant status and aberrant crypt foci development in rat colon carcinogenesis. Biochim. Biophys. Acta 2006, 1760, 1175-1183. [CrossRef]

84. Sener, G.; Topaloglu, N.; Ozer Sehirli, A.; Ercan, F.; Gedik, N. Resveratrol alleviates bleomycin-induced lung injury in rats. Pulm. Pharm. 2006, 20, 642-649. [CrossRef] [PubMed]

85. Jeganathan, V.S.; Wang, J.J.; Wong, T.Y. Ocular associations of diabetes other than diabetic retinopathy. Diabetes Care 2008, 31, 1905-1912. [CrossRef]

86. Bhatt, J.K.; Thomas, S.; Nanjan, M.J. Resveratrol supplementation improves glycemic control in type 2 diabetes mellitus. Nutr. Res. 2012, 32, 537-541. [CrossRef]

87. Poulsen, M.M.; Vestergaard, P.F.; Clasen, B.F.; Radko, Y.; Christensen, L.P.; Stodkilde-Jorgensen, H.; Moller, N.; Jessen, N.; Pedersen, S.B.; Jorgensen, J.O. High-dose resveratrol supplementation in obese men: An investigator-initiated, randomized, placebo-controlled clinical trial of substrate metabolism, insulin sensitivity, and body composition. Diabetes 2013, 62, $1186-1195$. [CrossRef]

88. Timmers, S.; Konings, E.; Bilet, L.; Houtkooper, R.H.; van de Weijer, T.; Goossens, G.H.; Hoeks, J.; van der Krieken, S.; Ryu, D.; Kersten, S.; et al. Calorie restriction-like effects of 30 days of resveratrol supplementation on energy metabolism and metabolic profile in obese humans. Cell Metab. 2011, 14, 612-622. [CrossRef]

89. Yoshino, J.; Conte, C.; Fontana, L.; Mittendorfer, B.; Imai, S.; Schechtman, K.B.; Gu, C.; Kunz, I.; Rossi Fanelli, F.; Patterson, B.W.; et al. Resveratrol supplementation does not improve metabolic function in nonobese women with normal glucose tolerance. Cell Metab. 2012, 16, 658-664. [CrossRef] 
90. Crandall, J.P.; Oram, V.; Trandafirescu, G.; Reid, M.; Kishore, P.; Hawkins, M.; Cohen, H.W.; Barzilai, N. Pilot study of resveratrol in older adults with impaired glucose tolerance. J. Gerontol. A Biol. Sci. Med. Sci. 2012, 67, 1307-1312. [CrossRef]

91. Brasnyo, P.; Molnar, G.A.; Mohas, M.; Marko, L.; Laczy, B.; Cseh, J.; Mikolas, E.; Szijarto, I.A.; Merei, A.; Halmai, R.; et al. Resveratrol improves insulin sensitivity, reduces oxidative stress and activates the Akt pathway in type 2 diabetic patients. Br. J. Nutr. 2011, 106, 383-389. [CrossRef]

92. Morselli, E.; Maiuri, M.C.; Markaki, M.; Megalou, E.; Pasparaki, A.; Palikaras, K.; Criollo, A.; Galluzzi, L.; Malik, S.A.; Vitale, I.; et al. The life span-prolonging effect of sirtuin-1 is mediated by autophagy. Autophagy 2010, 6, 186-188. [CrossRef]

93. Gurusamy, N.; Lekli, I.; Mukherjee, S.; Ray, D.; Ahsan, M.K.; Gherghiceanu, M.; Popescu, L.M.; Das, D.K. Cardioprotection by resveratrol: A novel mechanism via autophagy involving the mTORC2 pathway. Cardiovasc Res. 2010, 86, 103-112. [CrossRef]

94. Josifovska, N.; Albert, R.; Nagymihaly, R.; Lytvynchuk, L.; Moe, M.C.; Kaarniranta, K.; Vereb, Z.J.; Petrovski, G. Resveratrol as Inducer of Autophagy, Pro-Survival, and Anti-Inflammatory Stimuli in Cultured Human RPE Cells. Int. J. Mol. Sci. 2020, 21, 813. [CrossRef]

95. Koskela, A.; Reinisalo, M.; Petrovski, G.; Sinha, D.; Olmiere, C.; Karjalainen, R.; Kaarniranta, K. Nutraceutical with Resveratrol and Omega-3 Fatty Acids Induces Autophagy in ARPE-19 Cells. Nutrients 2016, 8, 284. [CrossRef]

96. Alaimo, A.; Di Santo, M.C.; Dominguez Rubio, A.P.; Chaufan, G.; Garcia Linares, G.; Perez, O.E. Toxic effects of A2E in human ARPE-19 cells were prevented by resveratrol: A potential nutritional bioactive for age-related macular degeneration treatment. Arch. Toxicol. 2020, 94, 553-572. [CrossRef]

97. Kang, J.H.; Choung, S.Y. Protective effects of resveratrol and its analogs on age-related macular degeneration in vitro. Arch. Pharm. Res. 2016, 39, 1703-1715. [CrossRef]

98. Limagne, E.; Lancon, A.; Delmas, D.; Cherkaoui-Malki, M.; Latruffe, N. Resveratrol Interferes with IL1-beta-Induced ProInflammatory Paracrine Interaction between Primary Chondrocytes and Macrophages. Nutrients 2016, 8, 280. [CrossRef]

99. Parmeggiani, F.; Romano, M.R.; Costagliola, C.; Semeraro, F.; Incorvaia, C.; D’Angelo, S.; Perri, P.; De Palma, P.; De Nadai, K.; Sebastiani, A. Mechanism of inflammation in age-related macular degeneration. Mediat. Inflamm. 2012, 2012, 546786. [CrossRef]

100. Chen, J.; Smith, L.E. Protective inflammasome activation in AMD. Nat. Med. 2012, 18, 658-660. [CrossRef]

101. Rosenbaum, J.T. Eyeing macular degeneration-Few inflammatory remarks. N. Engl. J. Med. 2012, 367, 768-770. [CrossRef]

102. Losso, J.N.; Truax, R.E.; Richard, G. trans-resveratrol inhibits hyperglycemia-induced inflammation and connexin downregulation in retinal pigment epithelial cells. J. Agric. Food Chem. 2010, 58, 8246-8252. [CrossRef]

103. Kutty, R.K.; Samuel, W.; Abay, R.; Cherukuri, A.; Nagineni, C.N.; Duncan, T.; Jaworski, C.; Vijayasarathy, C.; Redmond, T.M. Resveratrol attenuates CXCL11 expression induced by proinflammatory cytokines in retinal pigment epithelial cells. Cytokine 2015, 74, 335-338. [CrossRef]

104. Qin, S.; Lu, Y.; Rodrigues, G.A. Resveratrol protects RPE cells from sodium iodate by modulating PPARalpha and PPARdelta. Exp. Eye Res. 2014, 118, 100-108. [CrossRef]

105. Ferrara, N. Vascular endothelial growth factor and age-related macular degeneration: From basic science to therapy. Nat. Med. 2010, 16, 1107-1111. [CrossRef]

106. Kim, Y.H.; Kim, Y.S.; Roh, G.S.; Choi, W.S.; Cho, G.J. Resveratrol blocks diabetes-induced early vascular lesions and vascular endothelial growth factor induction in mouse retinas. Acta Ophthalmol. 2011, 89, e31-e37. [CrossRef]

107. Nagineni, C.N.; Raju, R.; Nagineni, K.K.; Kommineni, V.K.; Cherukuri, A.; Kutty, R.K.; Hooks, J.J.; Detrick, B. Resveratrol Suppresses Expression of VEGF by Human Retinal Pigment Epithelial Cells: Potential Nutraceutical for Age-related Macular Degeneration. Aging Dis. 2014, 5, 88-100. [CrossRef]

108. Balaiya, S.; Murthy, R.K.; Chalam, K.V. Resveratrol inhibits proliferation of hypoxic choroidal vascular endothelial cells. Mol. Vis. 2013, 19, 2385-2392.

109. Nagai, N.; Kubota, S.; Tsubota, K.; Ozawa, Y. Resveratrol prevents the development of choroidal neovascularization by modulating AMP-activated protein kinase in macrophages and other cell types. J. Nutr. Biochem. 2014, 25, 1218-1225. [CrossRef]

110. Quigley, H.A.; Broman, A.T. The number of people with glaucoma worldwide in 2010 and 2020. Br. J. Ophthalmol. 2006, 90, 262-267. [CrossRef]

111. Barkana, Y.; Dorairaj, S. Re: Tham et al.: Global prevalence of glaucoma and projections of glaucoma burden through 2040: A systematic review and meta-analysis (Ophthalmology 2014;121:2081-90). Ophthalmology 2015, 122, e40-e41. [CrossRef]

112. Hecht, I.; Achiron, A.; Man, V.; Burgansky-Eliash, Z. Modifiable factors in the management of glaucoma: A systematic review of current evidence. Graefes Arch. Clin. Exp. Ophthalmol. 2017, 255, 789-796. [CrossRef] [PubMed]

113. Bola, C.; Bartlett, H.; Eperjesi, F. Resveratrol and the eye: Activity and molecular mechanisms. Graefes Arch. Clin. Exp. Ophthalmol. 2014, 252, 699-713. [CrossRef] [PubMed]

114. Cao, K.; Ishida, T.; Fang, Y.; Shinohara, K.; Li, X.; Nagaoka, N.; Ohno-Matsui, K.; Yoshida, T. Protection of the Retinal Ganglion Cells: Intravitreal Injection of Resveratrol in Mouse Model of Ocular Hypertension. Investig. Ophthalmol. Vis. Sci. 2020, 61, 13. [CrossRef] [PubMed]

115. Zhang, X.; Feng, Y.; Wang, Y.; Wang, J.; Xiang, D.; Niu, W.; Yuan, F. Resveratrol ameliorates disorders of mitochondrial biogenesis and dynamics in a rat chronic ocular hypertension model. Life Sci. 2018, 207, 234-245. [CrossRef]

116. Ammar, D.A.; Hamweyah, K.M.; Kahook, M.Y. Antioxidants Protect Trabecular Meshwork Cells from Hydrogen PeroxideInduced Cell Death. Transl. Vis. Sci. Technol. 2012, 1, 4. [CrossRef] 
117. Ghosh, A.K.; Rao, V.R.; Wisniewski, V.J.; Zigrossi, A.D.; Floss, J.; Koulen, P.; Stubbs, E.B., Jr.; Kaja, S. Differential Activation of Glioprotective Intracellular Signaling Pathways in Primary Optic Nerve Head Astrocytes after Treatment with Different Classes of Antioxidants. Antioxidants (Basel) 2020, 9, 324. [CrossRef]

118. Chen, S.; Fan, Q.; Li, A.; Liao, D.; Ge, J.; Laties, A.M.; Zhang, X. Dynamic mobilization of PGC-1alpha mediates mitochondrial biogenesis for the protection of RGC-5 cells by resveratrol during serum deprivation. Apoptosis 2013, 18, 786-799. [CrossRef]

119. Goyal, A.; Srivastava, A.; Sihota, R.; Kaur, J. Evaluation of oxidative stress markers in aqueous humor of primary open angle glaucoma and primary angle closure glaucoma patients. Curr. Eye Res. 2014, 39, 823-829. [CrossRef]

120. Abu-Amero, K.K.; Kondkar, A.A.; Chalam, K.V. Resveratrol and Ophthalmic Diseases. Nutrients 2016, 8, 200. [CrossRef]

121. Pang, Y.; Qin, M.; Hu, P.; Ji, K.; Xiao, R.; Sun, N.; Pan, X.; Zhang, X. Resveratrol protects retinal ganglion cells against ischemia induced damage by increasing Opa1 expression. Int. J. Mol. Med. 2020, 46, 1707-1720. [CrossRef] [PubMed]

122. Yu, Z.; Yanxia, H.; Limin, G.; Yun, Z.; Mingxuan, Z.; Fuyao, X.; Cheng, T.; Jufang, H.; Dan, C. Melatonin alleviates pyroptosis of retinal neurons following acute intraocular hypertension. Cns Neurol. Disord. Drug Targets 2020. [CrossRef] [PubMed]

123. Seong, H.; Ryu, J.; Yoo, W.S.; Kim, S.J.; Han, Y.S.; Park, J.M.; Kang, S.S.; Seo, S.W. Resveratrol Ameliorates Retinal Ischemia/Reperfusion Injury in C57BL/6J Mice via Downregulation of Caspase-3. Curr. Eye Res. 2017, 42, 1650-1658. [CrossRef] [PubMed]

124. Luo, H.; Zhuang, J.; Hu, P.; Ye, W.; Chen, S.; Pang, Y.; Li, N.; Deng, C.; Zhang, X. Resveratrol Delays Retinal Ganglion Cell Loss and Attenuates Gliosis-Related Inflammation from Ischemia-Reperfusion Injury. Investig. Ophthalmol. Vis. Sci. 2018, 59, 3879-3888. [CrossRef] [PubMed]

125. Lindsey, J.D.; Duong-Polk, K.X.; Hammond, D.; Leung, C.K.; Weinreb, R.N. Protection of injured retinal ganglion cell dendrites and unfolded protein response resolution after long-term dietary resveratrol. Neurobiol. Aging 2015, 36, 1969-1981. [CrossRef]

126. Pasovic, L.; Eidet, J.R.; Lyberg, T.; Messelt, E.B.; Aabel, P.; Utheim, T.P. Antioxidants Improve the Viability of Stored Adult Retinal Pigment Epithelial-19 Cultures. Ophthalmol 2014, 3, 49-61. [CrossRef]

127. Avotri, S.; Eatman, D.; Russell-Randall, K. Effects of Resveratrol on Inflammatory Biomarkers in Glaucomatous Human Trabecular Meshwork Cells. Nutrients 2019, 11, 984. [CrossRef]

128. Luna, C.; Li, G.; Liton, P.B.; Qiu, J.; Epstein, D.L.; Challa, P.; Gonzalez, P. Resveratrol prevents the expression of glaucoma markers induced by chronic oxidative stress in trabecular meshwork cells. Food Chem. Toxicol. 2009, 47, 198-204. [CrossRef]

129. Razali, N.; Agarwal, R.; Agarwal, P.; Tripathy, M.; Kapitonova, M.Y.; Kutty, M.K.; Smirnov, A.; Khalid, Z.; Ismail, N.M. Topical trans-resveratrol ameliorates steroid-induced anterior and posterior segment changes in rats. Exp. Eye Res. 2016, 143, 9-16. [CrossRef]

130. Razali, N.; Agarwal, R.; Agarwal, P.; Kumar, S.; Tripathy, M.; Vasudevan, S.; Crowston, J.G.; Ismail, N.M. Role of adenosine receptors in resveratrol-induced intraocular pressure lowering in rats with steroid-induced ocular hypertension. Clin. Exp. Ophthalmol. 2015, 43, 54-66. [CrossRef]

131. Pearson, K.J.; Baur, J.A.; Lewis, K.N.; Peshkin, L.; Price, N.L.; Labinskyy, N.; Swindell, W.R.; Kamara, D.; Minor, R.K.; Perez, E.; et al. Resveratrol delays age-related deterioration and mimics transcriptional aspects of dietary restriction without extending life span. Cell Metab. 2008, 8, 157-168. [CrossRef] [PubMed]

132. Singh, A.; Bodakhe, S.H. Resveratrol delay the cataract formation against naphthalene-induced experimental cataract in the albino rats. J. Biochem. Mol. Toxicol. 2020, 34, e22420. [CrossRef] [PubMed]

133. Smith, A.J.O.; Eldred, J.A.; Wormstone, I.M. Resveratrol Inhibits Wound Healing and Lens Fibrosis: A Putative Candidate for Posterior Capsule Opacification Prevention. Investig. Ophthalmol. Vis. Sci. 2019, 60, 3863-3877. [CrossRef]

134. Zheng, T.; Lu, Y. SIRT1 Protects Human Lens Epithelial Cells against Oxidative Stress by Inhibiting p53-Dependent Apoptosis. Curr. Eye Res. 2016, 41, 1068-1075. [CrossRef] [PubMed]

135. Semeraro, F.; Morescalchi, F.; Cancarini, A.; Russo, A.; Rezzola, S.; Costagliola, C. Diabetic retinopathy, a vascular and inflammatory disease: Therapeutic implications. Diabetes Metab. 2019, 45, 517-527. [CrossRef]

136. Al-Shabrawey, M.; Smith, S. Prediction of diabetic retinopathy: Role of oxidative stress and relevance of apoptotic biomarkers. EPMA J. 2010, 1, 56-72. [CrossRef]

137. Li, J.; Yu, S.; Ying, J.; Shi, T.; Wang, P. Resveratrol Prevents ROS-Induced Apoptosis in High Glucose-Treated Retinal Capillary Endothelial Cells via the Activation of AMPK/Sirt1/PGC-1alpha Pathway. Oxid. Med. Cell Longev. 2017, 2017, 7584691. [CrossRef]

138. Fathalipour, M.; Eghtedari, M.; Borges, F.; Silva, T.; Moosavi, F.; Firuzi, O.; Mirkhani, H. Caffeic Acid Alkyl Amide Derivatives Ameliorate Oxidative Stress and Modulate ERK1/2 and AKT Signaling Pathways in a Rat Model of Diabetic Retinopathy. Chem. Biodivers 2019, 16, e1900405. [CrossRef]

139. Soufi, F.G.; Mohammad-Nejad, D.; Ahmadieh, H. Resveratrol improves diabetic retinopathy possibly through oxidative stressnuclear factor kappaB-apoptosis pathway. Pharm. Rep. 2012, 64, 1505-1514. [CrossRef]

140. Yar, A.S.; Menevse, S.; Dogan, I.; Alp, E.; Ergin, V.; Cumaoglu, A.; Aricioglu, A.; Ekmekci, A.; Menevse, A. Investigation of ocular neovascularization-related genes and oxidative stress in diabetic rat eye tissues after resveratrol treatment. J. Med. Food 2012, 15, 391-398. [CrossRef]

141. Reiter, C.E.; Wu, X.; Sandirasegarane, L.; Nakamura, M.; Gilbert, K.A.; Singh, R.S.; Fort, P.E.; Antonetti, D.A.; Gardner, T.W. Diabetes reduces basal retinal insulin receptor signaling: Reversal with systemic and local insulin. Diabetes 2006, 55, 1148-1156. [CrossRef] 
142. Mohammad, G.; Abdelaziz, G.M.; Siddiquei, M.M.; Ahmad, A.; De Hertogh, G.; Abu El-Asrar, A.M. Cross-Talk between Sirtuin 1 and the Proinflammatory Mediator High-Mobility Group Box-1 in the Regulation of Blood-Retinal Barrier Breakdown in Diabetic Retinopathy. Curr. Eye Res. 2019, 44, 1133-1143. [CrossRef]

143. Chen, Y.; Meng, J.; Li, H.; Wei, H.; Bi, F.; Liu, S.; Tang, K.; Guo, H.; Liu, W. Resveratrol exhibits an effect on attenuating retina inflammatory condition and damage of diabetic retinopathy via PON1. Exp. Eye Res. 2019, 181, 356-366. [CrossRef]

144. Ghadiri Soufi, F.; Arbabi-Aval, E.; Rezaei Kanavi, M.; Ahmadieh, H. Anti-inflammatory properties of resveratrol in the retinas of type 2 diabetic rats. Clin. Exp. Pharm. Physiol. 2015, 42, 63-68. [CrossRef]

145. Kowluru, R.A.; Santos, J.M.; Zhong, Q. Sirt1, a negative regulator of matrix metalloproteinase-9 in diabetic retinopathy. Investig. Ophthalmol. Vis. Sci. 2014, 55, 5653-5660. [CrossRef]

146. Higashi, Y.; Higashi, K.; Mori, A.; Sakamoto, K.; Ishii, K.; Nakahara, T. Anti-cataract Effect of Resveratrol in High-Glucose-Treated Streptozotocin-Induced Diabetic Rats. Biol. Pharm. Bull. 2018, 41, 1586-1592. [CrossRef]

147. Ciddi, V.; Dodda, D. Therapeutic potential of resveratrol in diabetic complications: In vitro and in vivo studies. Pharm. Rep. 2014, 66, 799-803. [CrossRef]

148. Li, G.; Luna, C.; Navarro, I.D.; Epstein, D.L.; Huang, W.; Gonzalez, P.; Challa, P. Resveratrol prevention of oxidative stress damage to lens epithelial cell cultures is mediated by forkhead box O activity. Investig. Ophthalmol. Vis. Sci. 2011, 52, 4395-4401. [CrossRef]

149. Zheng, Y.; Liu, Y.; Ge, J.; Wang, X.; Liu, L.; Bu, Z.; Liu, P. Resveratrol protects human lens epithelial cells against H2O2-induced oxidative stress by increasing catalase, SOD-1, and HO-1 expression. Mol. Vis. 2010, 16, 1467-1474.

150. Singh, A.; Bodakhe, S.H. Biochemical Evidence Indicates the Preventive Effect of Resveratrol and Nicotinamide in the Treatment of STZ-induced Diabetic Cataract. Curr. Eye Res. 2020, 1-12. [CrossRef]

151. Zeng, K.; Wang, Y.; Yang, N.; Wang, D.; Li, S.; Ming, J.; Wang, J.; Yu, X.; Song, Y.; Zhou, X.; et al. Resveratrol Inhibits DiabeticInduced Muller Cells Apoptosis through MicroRNA-29b/Specificity Protein 1 Pathway. Mol. Neurobiol. 2017, 54, 4000-4014. [CrossRef]

152. Zeng, K.; Yang, N.; Wang, D.; Li, S.; Ming, J.; Wang, J.; Yu, X.; Song, Y.; Zhou, X.; Yang, Y. Resveratrol Prevents Retinal Dysfunction by Regulating Glutamate Transporters, Glutamine Synthetase Expression and Activity in Diabetic Retina. Neurochem. Res. 2016, 41, 1050-1064. [CrossRef]

153. Nadeem, A.; Javaid, K.; Sami, W.; Zafar, A.; Jahan, S.; Zaman, S.; Nagi, A. Inverse relationship of serum IL-17 with type-II diabetes retinopathy. Clin. Lab. 2013, 59, 1311-1317. [CrossRef]

154. Liu, S.; Lin, Y.U.; Liu, X. Protective effects of SIRT1 in patients with proliferative diabetic retinopathy via the inhibition of IL-17 expression. Exp. Med. 2016, 11, 257-262. [CrossRef]

155. Limagne, E.; Thibaudin, M.; Euvrard, R.; Berger, H.; Chalons, P.; Vegan, F.; Humblin, E.; Boidot, R.; Rebe, C.; Derangere, V.; et al. Sirtuin-1 Activation Controls Tumor Growth by Impeding Th17 Differentiation via STAT3 Deacetylation. Cell Rep. 2017, 19, 746-759. [CrossRef]

156. Charteris, D.G. Proliferative vitreoretinopathy: Pathobiology, surgical management, and adjunctive treatment. Br. J. Ophthalmol. 1995, 79, 953-960. [CrossRef]

157. Chen, C.L.; Chen, Y.H.; Tai, M.C.; Liang, C.M.; Lu, D.W.; Chen, J.T. Resveratrol inhibits transforming growth factor-beta2-induced epithelial-to-mesenchymal transition in human retinal pigment epithelial cells by suppressing the Smad pathway. Drug Des. Devel. 2017, 11, 163-173. [CrossRef]

158. Ishikawa, K.; He, S.; Terasaki, H.; Nazari, H.; Zhang, H.; Spee, C.; Kannan, R.; Hinton, D.R. Resveratrol inhibits epithelialmesenchymal transition of retinal pigment epithelium and development of proliferative vitreoretinopathy. Sci. Rep. 2015, 5, 16386. [CrossRef]

159. Chan, C.M.; Chang, H.H.; Wang, V.C.; Huang, C.L.; Hung, C.F. Inhibitory effects of resveratrol on PDGF-BB-induced retinal pigment epithelial cell migration via PDGFRbeta, PI3K/Akt and MAPK pathways. PLoS ONE 2013, 8, e56819. [CrossRef]

160. Aqeel, Y.; Iqbal, J.; Siddiqui, R.; Gilani, A.H.; Khan, N.A. Anti-Acanthamoebic properties of resveratrol and demethoxycurcumin. Exp. Parasitol. 2012, 132, 519-523. [CrossRef]

161. Chan, M.M. Antimicrobial effect of resveratrol on dermatophytes and bacterial pathogens of the skin. Biochem. Pharm. 2002, 63, 99-104. [CrossRef]

162. Tsai, T.Y.; Chen, T.C.; Wang, I.J.; Yeh, C.Y.; Su, M.J.; Chen, R.H.; Tsai, T.H.; Hu, F.R. The effect of resveratrol on protecting corneal epithelial cells from cytotoxicity caused by moxifloxacin and benzalkonium chloride. Investig. Ophthalmol. Vis. Sci. 2015, 56, 1575-1584. [CrossRef] [PubMed]

163. Kubota, S.; Kurihara, T.; Ebinuma, M.; Kubota, M.; Yuki, K.; Sasaki, M.; Noda, K.; Ozawa, Y.; Oike, Y.; Ishida, S.; et al. Resveratrol prevents light-induced retinal degeneration via suppressing activator protein-1 activation. Am. J. Pathol. 2010, 177, $1725-1731$. [CrossRef]

164. Zhang, H.; He, S.; Spee, C.; Ishikawa, K.; Hinton, D.R. SIRT1 mediated inhibition of VEGF/VEGFR2 signaling by Resveratrol and its relevance to choroidal neovascularization. Cytokine 2015, 76, 549-552. [CrossRef]

165. Maugeri, A.; Barchitta, M.; Mazzone, M.G.; Giuliano, F.; Basile, G.; Agodi, A. Resveratrol Modulates SIRT1 and DNMT Functions and Restores LINE-1 Methylation Levels in ARPE-19 Cells under Oxidative Stress and Inflammation. Int. J. Mol. Sci. 2018, 19, 2118. [CrossRef] [PubMed]

166. Peng, L.; Yuan, Z.; Ling, H.; Fukasawa, K.; Robertson, K.; Olashaw, N.; Koomen, J.; Chen, J.; Lane, W.S.; Seto, E. SIRT1 deacetylates the DNA methyltransferase 1 (DNMT1) protein and alters its activities. Mol. Cell Biol. 2011, 31, 4720-4734. [CrossRef] 
167. Kubota, S.; Ozawa, Y.; Kurihara, T.; Sasaki, M.; Yuki, K.; Miyake, S.; Noda, K.; Ishida, S.; Tsubota, K. Roles of AMP-activated protein kinase in diabetes-induced retinal inflammation. Investig. Ophthalmol. Vis. Sci. 2011, 52, 9142-9148. [CrossRef]

168. Michan, S.; Juan, A.M.; Hurst, C.G.; Cui, Z.; Evans, L.P.; Hatton, C.J.; Pei, D.T.; Ju, M.; Sinclair, D.A.; Smith, L.E.; et al. Sirtuin1 over-expression does not impact retinal vascular and neuronal degeneration in a mouse model of oxygen-induced retinopathy. PLoS ONE 2014, 9, e85031. [CrossRef]

169. Kadiyala, C.S.; Zheng, L.; Du, Y.; Yohannes, E.; Kao, H.Y.; Miyagi, M.; Kern, T.S. Acetylation of retinal histones in diabetes increases inflammatory proteins: Effects of minocycline and manipulation of histone acetyltransferase (HAT) and histone deacetylase (HDAC). J. Biol. Chem. 2012, 287, 25869-25880. [CrossRef]

170. Pandian, S.; Jeevanesan, V.; Ponnusamy, C.; Natesan, S. RES-loaded pegylated CS NPs: For efficient ocular delivery. Iet. Nanobiotechnol. 2017, 11, 32-39. [CrossRef]

171. Natesan, S.; Pandian, S.; Ponnusamy, C.; Palanichamy, R.; Muthusamy, S.; Kandasamy, R. Co-encapsulated resveratrol and quercetin in chitosan and peg modified chitosan nanoparticles: For efficient intra ocular pressure reduction. Int. J. Biol. Macromol. 2017, 104, 1837-1845. [CrossRef] [PubMed]

172. Bhatt, P.; Fnu, G.; Bhatia, D.; Shahid, A.; Sutariya, V. Nanodelivery of Resveratrol-Loaded PLGA Nanoparticles for Age-Related Macular Degeneration. AAPS PharmSciTech 2020, 21, 291. [CrossRef] [PubMed]

173. Rugina, D.; Ghiman, R.; Focsan, M.; Tabaran, F.; Copaciu, F.; Suciu, M.; Pintea, A.; Astilean, S. Resveratrol-delivery vehicle with anti-VEGF activity carried to human retinal pigmented epithelial cells exposed to high-glucose induced conditions. Colloids Surf. B Biointerfaces 2019, 181, 66-75. [CrossRef] [PubMed]

174. Vora, D.; Heruye, S.; Kumari, D.; Opere, C.; Chauhan, H. Preparation, Characterization and Antioxidant Evaluation of Poorly Soluble Polyphenol-Loaded Nanoparticles for Cataract Treatment. AAPS PharmSciTech 2019, 20, 163. [CrossRef]

175. Valdes-Sanchez, L.; Garcia-Delgado, A.B.; Montero-Sanchez, A.; de la Cerda, B.; Lucas, R.; Penalver, P.; Morales, J.C.; Bhattacharya, S.S.; Diaz-Corrales, F.J. The Resveratrol Prodrug JC19 Delays Retinal Degeneration in rd10 Mice. Adv. Exp. Med. Biol. 2019, 1185, 457-462. [CrossRef]

176. Ghanim, H.; Sia, C.L.; Korzeniewski, K.; Lohano, T.; Abuaysheh, S.; Marumganti, A.; Chaudhuri, A.; Dandona, P. A resveratrol and polyphenol preparation suppresses oxidative and inflammatory stress response to a high-fat, high-carbohydrate meal. J. Clin. Endocrinol. Metab. 2011, 96, 1409-1414. [CrossRef]

177. Lin, C.T.; Sun, X.Y.; Lin, A.X. Supplementation with high-dose trans-resveratrol improves ultrafiltration in peritoneal dialysis patients: A prospective, randomized, double-blind study. Ren Fail. 2016, 38, 214-221. [CrossRef]

178. Richer, S.; Stiles, W.; Ulanski, L.; Carroll, D.; Podella, C. Observation of human retinal remodeling in octogenarians with a resveratrol based nutritional supplement. Nutrients 2013, 5, 1989-2005. [CrossRef]

179. Richer, S.; Patel, S.; Sockanathan, S.; Ulanski, L.J., 2nd; Miller, L.; Podella, C. Resveratrol based oral nutritional supplement produces long-term beneficial effects on structure and visual function in human patients. Nutrients 2014, 6, 4404-4420. [CrossRef]

180. Wang, S.; Moonasar, N.; Xiao, X.; Yin, T.; Weinreb, R.N.; Sun, X. Effect of Resveratrol-Based Nutritional Supplement on Choroidal Thickness: A Pilot Study. Curr. Eye Res. 2016, 41, 1339-1345. [CrossRef]

181. Pirhan, D.; Yuksel, N.; Emre, E.; Cengiz, A.; Kursat Yildiz, D. Riluzole- and Resveratrol-Induced Delay of Retinal Ganglion Cell Death in an Experimental Model of Glaucoma. Curr. Eye Res. 2016, 41, 59-69. [CrossRef] [PubMed]

182. Subramani, M.; Ponnalagu, M.; Krishna, L.; Jeyabalan, N.; Chevour, P.; Sharma, A.; Jayadev, C.; Shetty, R.; Begum, N.; Archunan, G.; et al. Resveratrol reverses the adverse effects of bevacizumab on cultured ARPE-19 cells. Sci. Rep. 2017, 7, 12242. [CrossRef] [PubMed]

183. Pozarowska, D.; Pozarowski, P. The era of anti-vascular endothelial growth factor (VEGF) drugs in ophthalmology, VEGF and anti-VEGF therapy. Cent. Eur. J. Immunol. 2016, 41, 311-316. [CrossRef] [PubMed]

184. Kwong, T.Q.; Mohamed, M. Anti-vascular endothelial growth factor therapies in ophthalmology: Current use, controversies and the future. Br. J. Clin. Pharm. 2014, 78, 699-706. [CrossRef]

185. Billard, C.; Izard, J.C.; Roman, V.; Kern, C.; Mathiot, C.; Mentz, F.; Kolb, J.P. Comparative antiproliferative and apoptotic effects of resveratrol, epsilon-viniferin and vine-shots derived polyphenols (vineatrols) on chronic B lymphocytic leukemia cells and normal human lymphocytes. Leuk Lymphoma 2002, 43, 1991-2002. [CrossRef]

186. Clement, M.V.; Hirpara, J.L.; Chawdhury, S.H.; Pervaiz, S. Chemopreventive agent resveratrol, a natural product derived from grapes, triggers CD95 signaling-dependent apoptosis in human tumor cells. Blood 1998, 92, 996-1002. [CrossRef]

187. Lu, J.; Ho, C.H.; Ghai, G.; Chen, K.Y. Resveratrol analog, 3,4,5,4'-tetrahydroxystilbene, differentially induces pro-apoptotic p53/Bax gene expression and inhibits the growth of transformed cells but not their normal counterparts. Carcinogenesis 2001, 22, 321-328. [CrossRef]

188. Colin, D.; Gimazane, A.; Lizard, G.; Izard, J.C.; Solary, E.; Latruffe, N.; Delmas, D. Effects of resveratrol analogs on cell cycle progression, cell cycle associated proteins and 5fluoro-uracil sensitivity in human derived colon cancer cells. Int. J. Cancer 2009, 124, 2780-2788. [CrossRef]

189. Brown, V.A.; Patel, K.R.; Viskaduraki, M.; Crowell, J.A.; Perloff, M.; Booth, T.D.; Vasilinin, G.; Sen, A.; Schinas, A.M.; Piccirilli, G.; et al. Repeat dose study of the cancer chemopreventive agent resveratrol in healthy volunteers: Safety, pharmacokinetics, and effect on the insulin-like growth factor axis. Cancer Res. 2010, 70, 9003-9011. [CrossRef]

190. Walle, T.; Hsieh, F.; DeLegge, M.H.; Oatis, J.E., Jr.; Walle, U.K. High absorption but very low bioavailability of oral resveratrol in humans. Drug. Metab. Dispos. 2004, 32, 1377-1382. [CrossRef] 
191. Boocock, D.J.; Faust, G.E.; Patel, K.R.; Schinas, A.M.; Brown, V.A.; Ducharme, M.P.; Booth, T.D.; Crowell, J.A.; Perloff, M.; Gescher, A.J.; et al. Phase I dose escalation pharmacokinetic study in healthy volunteers of resveratrol, a potential cancer chemopreventive agent. Cancer Epidemiol. Biomark. Prev. 2007, 16, 1246-1252. [CrossRef] [PubMed]

192. Almeida, L.; Vaz-da-Silva, M.; Falcao, A.; Soares, E.; Costa, R.; Loureiro, A.I.; Fernandes-Lopes, C.; Rocha, J.F.; Nunes, T.; Wright, L.; et al. Pharmacokinetic and safety profile of trans-resveratrol in a rising multiple-dose study in healthy volunteers. Mol. Nutr. Food. Res. 2009, 53, S7-S15. [CrossRef] [PubMed]

193. Nunes, T.; Almeida, L.; Rocha, J.F.; Falcao, A.; Fernandes-Lopes, C.; Loureiro, A.I.; Wright, L.; Vaz-da-Silva, M.; Soares-da-Silva, P. Pharmacokinetics of trans-resveratrol following repeated administration in healthy elderly and young subjects. J. Clin. Pharm. 2009, 49, 1477-1482. [CrossRef] [PubMed]

194. Wang, S.; Wang, Z.; Yang, S.; Yin, T.; Zhang, Y.; Qin, Y.; Weinreb, R.N.; Sun, X. Tissue Distribution of trans-Resveratrol and Its Metabolites after Oral Administration in Human Eyes. J. Ophthalmol. 2017, 2017, 4052094. [CrossRef] 